\title{
Single cell induced starvation in a high temperature proton exchange membrane fuel cell stack
}

\author{
Cinthia Alegre ${ }^{1}$, Antonio Lozano ${ }^{1}$, Ángel Pérez Manso² ${ }^{2}$ Laura Álvarez-Manuel ${ }^{1}$, \\ Florencio Fernández Marzo², Félix Barreras ${ }^{1, \S}$ \\ ${ }^{1}$ LIFTEC, CSIC-Univ. of Zaragoza, C/ María de Luna, 10. 50018, Zaragoza (SPAIN) \\ ${ }^{2}$ Escuela de Ingeniería de Guipúzcoa, University of the Basque Country, UPV-EHU, Plaza de Europa, 1. 200018,
}

San Sebastián (SPAIN)

\begin{abstract}
Fuel and oxidant starvation are amongst the most critical phenomena affecting fuel cell durability. Reactant starvation during proton exchange membrane fuel cell operation can cause serious irreversible damages. In the present research, the effect of a selective induced starvation of reactant gases on the performance and degradation of a high-temperature PEM fuel cell is studied. A specifically designed 5-cell stack is used, which enables varying the gas supplied to any of the individual cells. The particularity of selectively starving only one cell in a controlled manner is one of the novelties of this study. Two different tests are performed actuating on the central cell (cell 3). They are denoted as moderate and severe starvation, depending on the intensity of the limitation imposed to the gases flowrate. Some relevant and novel results are obtained. It is verified that the performance degradation caused by a moderate starvation of the reactant gases in a cell is reversible. On the contrary, the damages caused by an aggressive gas starvation, which is also maintained in time (30 min.), are irreversible. However, the behavior of the rest of the cells is barely affected by the gas starvation to cell 3 . Thus, the other major novelty of the present work is the evidence/proof of the ability of a stack with a starved and highly degraded cell, to continue operating, although with a drastic reduction in the total generated current.
\end{abstract}

Keywords: proton exchange membrane fuel cell; stack; high temperature; starvation; membrane-electrode assembly degradation

\footnotetext{
§ Corresponding author: felix@litec.csic.es
} 


\section{1.- INTRODUCTION}

One of the main concerns of modern societies is the preservation of a clean air. This is clearly reflected in the increasingly stricter legislation to limit emissions of both pollutant and greenhouse effect gases [1], [2], [3]. In this context, fuel cells based on proton-exchange membranes (PEMFC) can be the future solution for a clean and efficient energy conversion [4], [5], [6]. They can be used either in transportation to gradually replace internal combustion engine cars by fuel cell hybrid electric vehicles [5], [7], [8], [9] or in stationary applications to be integrated in micro-combined heat and power (CHP) units [5], [10], [11], [12]. Recent advances in this type of PEMFCs have been focused on the development of devices that operate above $100^{\circ} \mathrm{C}$, which are commonly denoted as high-temperature PEM fuel cells (HTPEMFC). HT-PEMFCs are usually based on a phosphoric acid doped polybenzimidazole (PBI) membrane [13], [14], which allows the operation at temperatures ranging from $120^{\circ} \mathrm{C}$ to $180^{\circ} \mathrm{C}$. This entails several advantages over traditional low-temperature PEMFCs [15], [16]. Among others, one can cite the enhancement of the electrochemical kinetics for both anode and cathode reactions [17], [18]; the increase in the CO tolerance; and the simplification of the water management systems. Finally, HT-PEMFCs are simple and reliable devices because complicated humidification subsystems can be avoided, and cooling systems are drastically simplified due to the increase in temperature gradient between fuel cell stack and coolant [14].

Although great advances have been made in PEM fuel cell technology in the last years, there are several issues concerning durability and performance degradation that still limit their commercialization [19], [20], [21]. According to DOE reports, PEMFCs should last for $5000 \mathrm{~h}$ for automotive applications and around 60,000 h for stationary ones [22], [23], [24]. Even though during the last few years important progress has been achieved on these subjects [25], [26], [27], the lifetime of HT-PEMFCs under variable load conditions needs to be enhanced. A phenomenon that has a significant impact on the performance deterioration of PEMFCs is the starvation of reactant gases. Starvation can occur during normal operation of single cells or stacks if the flow rate of the feeding reactant gases decreases [33]. Sometimes this can be the result of flooding that blocks, at least partially or locally, the porous layer of both electrodes obstructing the gas transport to the reaction sites. Starvation of reactant gases can be easily reduced by increasing the fuel and air flow rates, but it is neither an optimum solution from an economic point of view nor an efficient approach to improve the fuel cell performance [34]. 
Gas starvation induces strong degradation in the catalyst layers due to the corrosive potentials reached, considerably decreasing the durability of the electrodes [35]. It is generally believed that when a cell suffers voltage reversal in a stack, the neighboring cells follow the same trend [36] ,[37], [38], [39], [40], [41]. The effects of both hydrogen and oxygen starvation naturally occurring in low-temperature PEMFCs have been reported in the literature [37], [38], [39], [42], [43], [44], [45]. On the contrary, very few studies have been focused on HT-PEM fuel cells [46], and most of them are concerned with phosphoric acid fuel cells (PAFC), which use similar electrolyte and catalyst layers to PBI-based HT-PEM fuel cells [47], [48], or with single cells [49], [50].

The present research is aimed to analyze the effect of the induced starvation of reactant gases, in particular hydrogen, on the performance and degradation of the starving cell and its neighbors. The novelty of this study resides in the particularity of starving a specific single cell, and on the analysis of the behavior and features of the neighboring ones. This issue has not received the required attention in previous studies. A specially designed 5-cell stack was used, which enables specific variations of the gas supplied to any of the individual cells. Two types of tests were performed acting on cell 3 (central) denoted as moderate and severe starvation, respectively. The difference between them depended on the intensity of the limitation imposed to the gases flowrate. In all the tests, the voltage of each cell was monitored. The temperature of the different plates of the stack was measured using a thermal infrared camera, and the phosphorus and platinum in samples of water collected from both anode and cathode sides was determined by inductive coupled plasma atomic emission spectrometry (ICP-AES). MEAs from each cell (from 1 to 5 ) were analyzed after the tests by transmission and scanning electron microscopy, and by X-ray diffraction in order to determine the extent of degradation caused by starvation on one cell.

\section{2.- Experimental}

\section{1.- Stack design and assembly}

As depicted in Fig. 1, the stack consists of 5 cells with individual gas supply to each one of them. It is formed by six JP-945 graphite bipolar plates manufactured by Mersen, (suitable for working temperatures up to $200^{\circ} \mathrm{C}$ ), $280 \mathrm{~mm}$ high, $195 \mathrm{~mm}$ wide, and with a thickness of 5 $\mathrm{mm}$, as well as two end plates of stainless steel where all the connectors for the reactant 
gases, $\mathrm{H}_{2}$ and $\mathrm{O}_{2}$, are placed. The flowfield geometry in both anode and cathode sides consisted of straight parallel channels with a land-to-channel ratio of 1 , as recommended by the MEA manufacturer. The anode side was formed by 47 channels with a width of $1 \mathrm{~mm}$, a depth of $1.5 \mathrm{~mm}$, and a total length of $210 \mathrm{~mm}$. The cathode side flowfield geometry consisted in 87 channels with a width of $1 \mathrm{~mm}$ and a depth of $2 \mathrm{~mm}$, and a total length of $120 \mathrm{~mm}$. With this design, pressure losses were minimized to $5.87 \mathrm{~Pa}$ in the anode and 2.6 $\mathrm{Pa}$ in the cathode, ensuring both the homogenous distribution of the reactant gases over the electrodes [51], [52] and the correct water management [53].

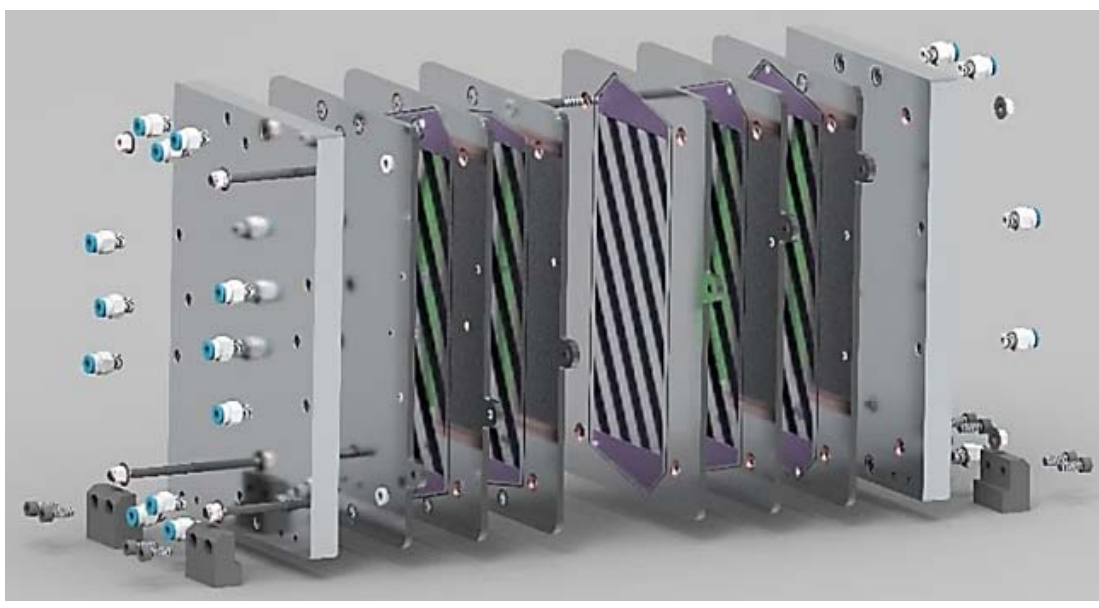

a)

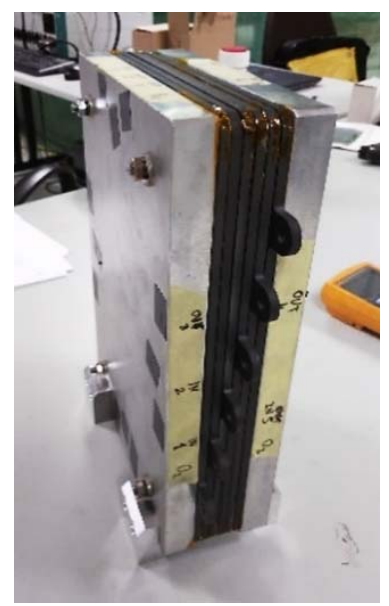

b)

Figure 1. SolidEDGE image of the stack design (a), and a photo of the stack assembled ready for tests (b)

Commercial high-temperature membrane-electrode assemblies (MEAs) G1018 Dapozol ${ }^{\circledR}-100$, manufactured by Danish Power System ${ }^{\circledR}$ (DPS) with a rectangular active area of $163.5 \mathrm{~cm}^{2}$, were used. The MEAs are formed by $\mathrm{H}_{3} \mathrm{PO}_{4}$ doped $\mathrm{PBI}$ proton conducting membranes, with a nominal thickness of $650 \pm 50 \mu \mathrm{m}$, gas diffusion layers (GDLs) of non-woven carbon paper and a platinum load of $1.5 \mathrm{mg} \mathrm{cm}^{-2}$ in both electrodes. The nominal thickness of the electrodes is $250 \mu \mathrm{m}$, which includes the GDL, the microporous layer and the catalyst layer. On the other hand, the thickness of the un-doped PBI-polymer is $40 \mu \mathrm{m}$, increasing up to $60-80 \mu \mathrm{m}$ after being doped with phosphoric acid. To obtain the best results, a minimum compression rate of $13 \%$ is advised. The recommended working temperature ranges from $150^{\circ} \mathrm{C}$ to $170^{\circ} \mathrm{C}$ [54]. To avoid either gas leaks outside the stack (very critical for hydrogen) or crossover between cathode and anode, a sealing system was carefully designed. A rectangular groove $1.5 \mathrm{~mm}$ wide and $1 \mathrm{~mm}$ deep was machined surrounding each gas supply orifice and the flowfield geometry, to house a cord of Loctite ${ }^{\circledR} 5910$ deposited on it. The silicone was automatically 
deposited into the sealing channels using a I\&J Fisnar I\&J2500N 3-D Cartesian desktop dispensing robot. The final size of the gasket was controlled simultaneously regulating the injection pressure, the diameter of the needle, and the displacement speed [10].

The stack was assembled inside a greenhouse in the laboratory to guarantee adequate humidity conditions. To decrease the relative humidity inside the greenhouse, dry compressed air was injected using two pipes connected to the main air pressure line. A complete description and illustrative photos of this facility can be consulted in [10]. To ensure the correct sealing of the reactant gases, the upper and lower edges of each MEA were stuck with Kapton $^{\mathrm{TM}}$ tape over the cathode side of the plates. Machined Teflon washers were placed in the holes through which the four locking screws were passed to help aligning the different plates during the assembling, and to avoid over-tightening the MEAs when closing the stack. A hydraulic press was used to close the stack with a tightening force of about $3 \mathrm{~N}-\mathrm{m}$ in each screw.

\section{2.- Experimental setup}

All the experimental tests were performed in the dual test bench of the LIFTEC. The stack was heated using two Roweld Quick S industrial air heaters, which can reach air temperatures up to $700^{\circ} \mathrm{C}$. To minimize the heating time, and to ensure a homogeneous heating, the stack was placed inside a box formed by 5 plates of a thermal insulating material, leaving its front part open. This strategy allows reaching stack wall temperatures close to $200^{\circ} \mathrm{C}$. The experimental assembly is shown in the two photos of Fig. 2. To control the stack operation, it was connected to an IT-8514-F dynamic electric load.
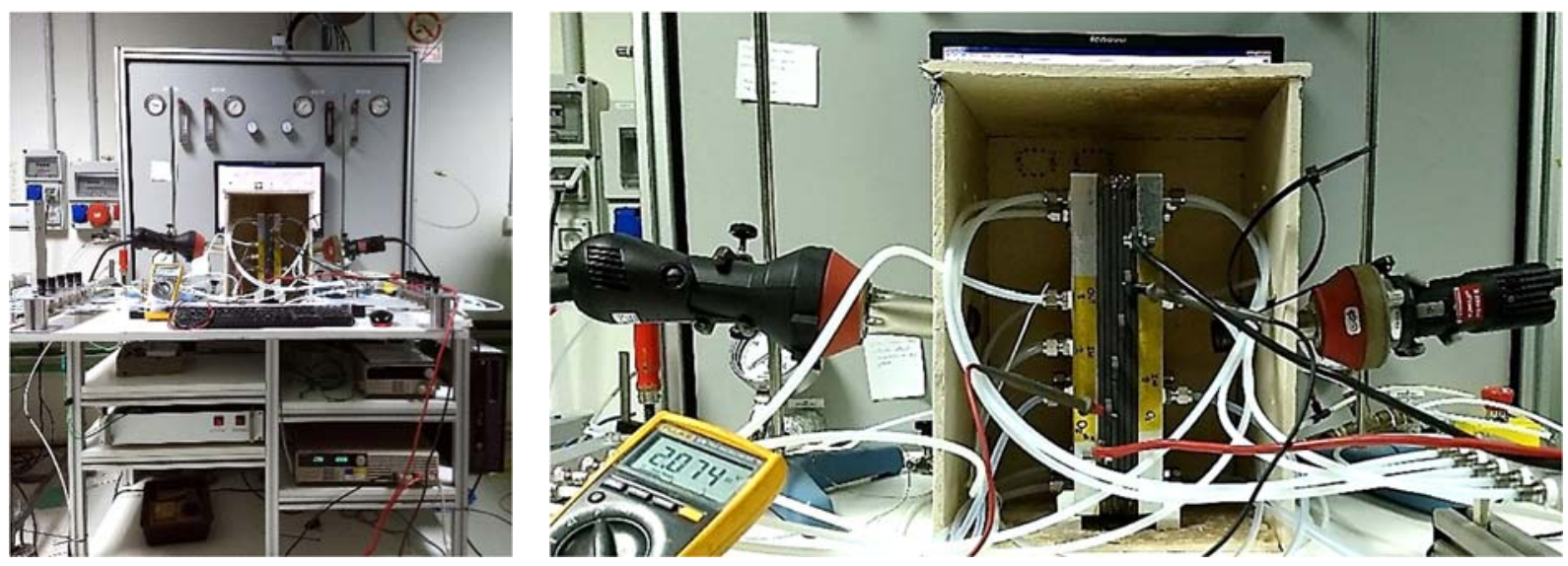

Figure 2. Experimental setup of the 5-cell stack in the dual test bench

One of the aims of the designed stack was to vary independently the gas flow supplied to each 
cell in order to study the influence of gas starvation on the performance of the starving cell and its neighbors. For this reason, 10 low pressure valves were used for an efficient control of the gas flow, 5 for each reactant gases, assembled in separate racks. In order to know the exact gas flow supplied, an accurate calibration of the flow rate was performed using the mass flow controllers of the test bench. The flow was changed varying the number of turns of the micrometric screw in the valves for different inlet gas pressures.

\section{3.- Start-up, break-in and shut-down procedures}

DPS recommends that before supplying gases to the stack (or cell) with its MEA, it should be heated to $120^{\circ} \mathrm{C}$. Once fuel is present, a stoichiometry above 1.5 should be ensured in order to avoid gas starvation, and a minimum current of $100 \mathrm{~mA} \mathrm{~cm}^{-2}(16.35 \mathrm{~A})$ must be drawn. The activation procedure enables the MEA to reach a higher performance. During the break-in stage, stack temperature was kept at $160^{\circ} \mathrm{C}$, and a constant current of $32.7 \mathrm{~A}\left(0.2 \mathrm{~A} \mathrm{~cm}^{-2}\right)$ was drawn. The gas stoichiometry was set to 1.7 and 3.0 for hydrogen and oxygen, respectively. To speed up the performance increase, several polarization curves were run up to a maximum current density of $1 \mathrm{~A} \mathrm{~cm}^{-2}$ during this period. Due to some limitations in the experimental facility, the total time spent for the stack conditioning was 22.5 hours distributed in three days. To shut the stack down, the current drawn was limited to $16.35 \mathrm{~A}\left(0.1 \mathrm{~A} \mathrm{~cm}^{-2}\right)$, the flowrate of the reactant gases was fitted to this current and the resistance of the external heat sources were turned off. When the stack temperature decreased to $120^{\circ} \mathrm{C}$, the current demanded for the dynamic electric load was set to cero and the solenoid valves of the gas supply lines were closed, letting the stack to cool down to room temperature.

\section{4.- Starvation tests}

To perform the induced degradation tests, the stack was initially heated up to $140^{\circ} \mathrm{C}$. Reactant

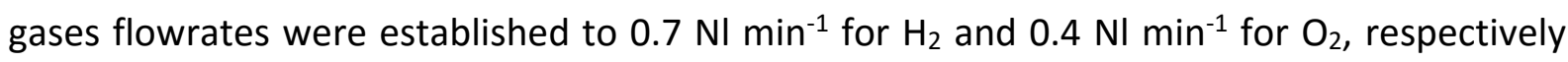
and a current of $16.35 \mathrm{~A}$ was demanded during 10 minutes, in order to ensure a constant delivered voltage and a constant working stack temperature of $160^{\circ} \mathrm{C}$. Subsequently, the current was increased stepwise to reach $32.7 \mathrm{~A}$, adjusting the reactant gases flowrates to the corresponding values for a stoichiometry of 1.15 for hydrogen and 1.25 for oxygen. It is important to note that the performance of the stack was analyzed under steady-state conditions just before and after the induced starvation tests. In these tests, the demanded 
current was kept constant at $32.7 \mathrm{~A}$, and an average working temperature of $160^{\circ} \mathrm{C}$ was also established.

\subsection{1.- Moderate starvation of the reactant gases induced in the central cell}

To induce the "moderate starvation" of reactant gases to cell 3 (central), the flowrate was reduced $20 \%$ of that corresponding to stoichiometric flow conditions $\left(\lambda_{\mathrm{H} 2}=\lambda_{\mathrm{O} 2}=1\right)$ for the demanded current of $32.7 \mathrm{~A}$. Thus, the flow of hydrogen to cell 3 was set to $0.2 \mathrm{NI} \mathrm{min}^{-1}(0.25$

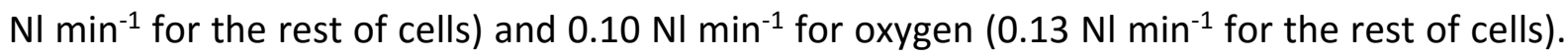
The cell was maintained in this operating conditions for 30 minutes. This test is identified as T20/30, indicating the reduction of reactant gases (20\%) and the time of the test (30 min.).

\subsection{2.- Severe starvation of the reactant gases induced in the central cell}

For the "severe starvation" tests, the flowrate of reactant gases was reduced from $100 \%$ to $50 \%$ in $10 \%$ steps. The cell operated for 15 minutes in each one of these steps. In the final condition ( $50 \%$ of the flow) the cell was maintained in operation for 30 minutes, and after this time the flowrate of both gases was set again to $100 \%$. This test is identified as T50/30. It is also important to note that this test was performed the day after the "moderate starvation" one. In a different day, another severe starvation test was performed, operating the central cell with the same gas starvation (50\%), but maintaining this condition for 2 hours. This test is identified as T50/120.

\section{5.- Physical and chemical characterization}

The temperature of the different plates of the stack was measured using infrared thermography. To this end, a thermal infrared FLIR T-200 camera was used. A good thermal image quality resolution was obtained with an uncooled microbolometer array formed by 240x180 pixels, covering a spectral range from $7.5 \mu \mathrm{m}$ to $13 \mu \mathrm{m}$. This setup allows the measurement of the temperature of objects ranging from $-20^{\circ} \mathrm{C}$ to $+350^{\circ} \mathrm{C}$ with a thermal sensitivity of $80 \mathrm{mK}$ noise equivalent temperature difference (NETD). A $25 \mathrm{~mm}$ lens ensures a minimum focusing distance of $0.4 \mathrm{~m}$. For these experiments, the camera was placed perpendicular to the stack plates at a proper distance to focus the entire area.

MEAs were analyzed by different characterization techniques before and after the performance/starvation tests, in order to investigate the effects of starvation on their physical-chemical characteristics. Morphological features of both fresh and used MEAs were 
observed by analyzing a cross-section with scanning electron microscopy coupled with energy dispersive X-ray spectroscopy, obtained with a Hitachi S-3400 N SEM-EDX, with an EDX Röntec XFlash analyzer of $\mathrm{Si}(\mathrm{Li})$, operated at $15 \mathrm{kV}$. Catalysts grafted from the MEAs prior to the tests and after them were also analyzed by X-Ray diffraction in a Bruker AXS D8 Advance diffractometer with a Bragg-Brentano $(\theta-\theta)$ configuration and using $\mathrm{Cu}-\mathrm{K} \alpha$ radiation, $40 \mathrm{kV}$ voltage and $40 \mathrm{~mA}$ current. Crystallite sizes of Pt were calculated from the Scherrer's equation on the (220) peak [55]. Particle size and morphology of Pt particles in both anode and cathode were investigated with transmission electron microscopy using a Tecnai F30 (Thermofisher, formerly FEI) microscope equipped with a Gatan CCD camera at $300 \mathrm{kV}$ working voltage.

Finally, samples of water obtained from the stack from both anode and cathode sides were also analyzed by atomic emission spectrometry coupled with inductive plasma (ICP-AES). The analysis focused on the determination of the phosphorus and platinum that could be dragged from the MEAs during the starvation tests.

\section{3.- Results}

It should be noted that bipolar plates with the flowfield geometries used in this experimental stack, manufactured in JP-945 graphite, and using the G1018 Dapozol ${ }^{\circledR} 100$ MEAs, manufactured by DPS will be used in a 45-cell stack. The expected nominal power is around $1.5 \mathrm{~kW}$, and it will be used as the power source of a combined heat and power unit of an isolated house.

\subsection{Break-in procedure}

Results of the voltage variation during the break-in procedure are depicted in Fig. 3, where a space of 30 minutes has been inserted in the curves to differentiate the performance of the three days. As shown in the figure, the average voltage of cells 1, 2, 3 and 4 was higher than $700 \mathrm{mV}$ for a current of $32.7 \mathrm{~A}\left(0.2 \mathrm{~A} \mathrm{~cm}^{-2}\right)$. These values are even better than those reported by DPS, where tests are performed in a single cell with an active area of $21 \mathrm{~cm}^{2}$ [44]. As can be observed, contrary to the rest of the cells, which delivered a voltage close to $700 \mathrm{mV}$, cell 5 started the break-in procedure providing a voltage around $660 \mathrm{mV}$, which dropped to 540 $\mathrm{mV}$ at the end of the first day. Its subsequent operation was not seriously affected, ending the activation period generating $515 \mathrm{mV}$ for this current. 


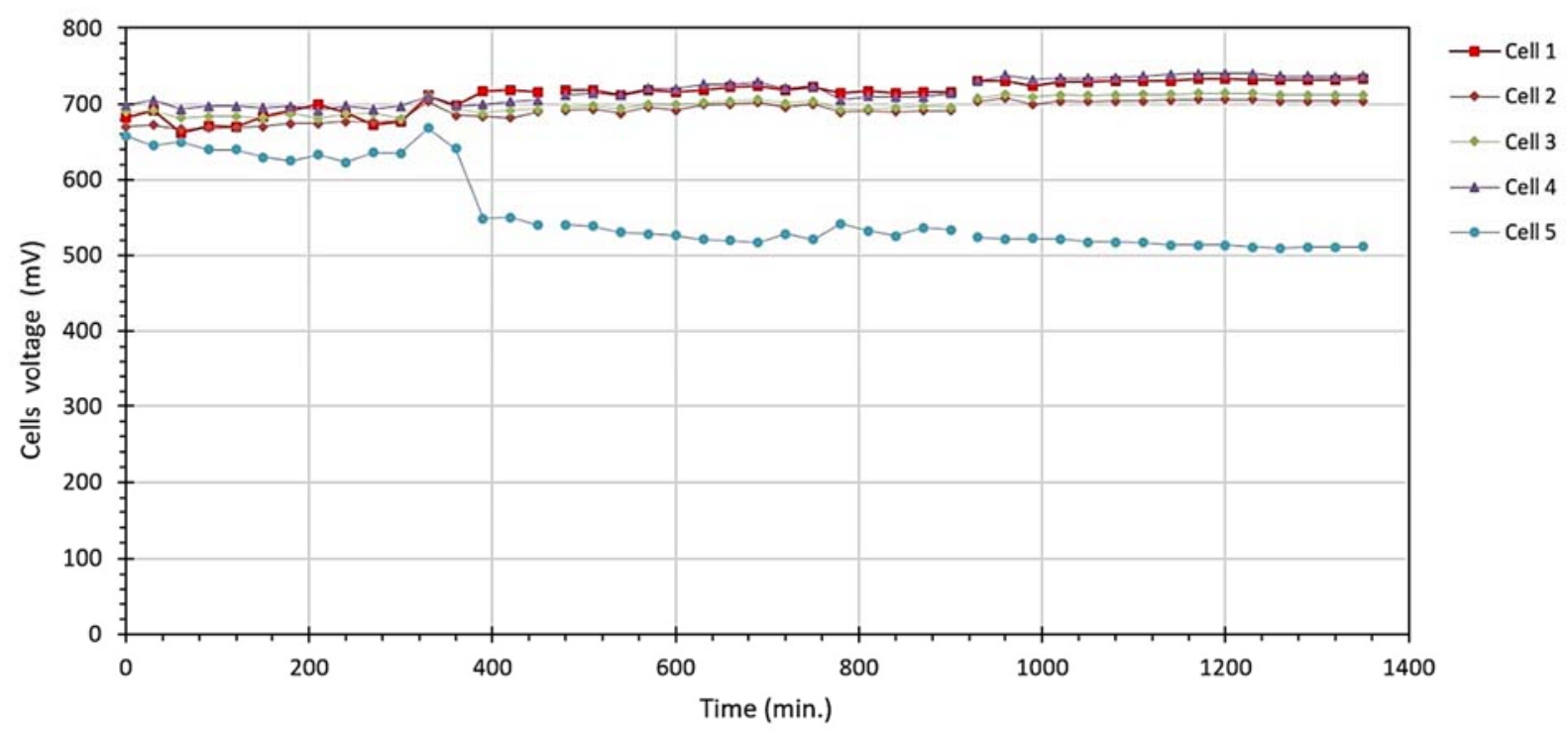

Figure 3. Variation of voltage with time of the 5-cell stack during break-in procedure

After the break-in procedure was completed, the degradation tests were performed, inducing gas starvation in the central cell.

\subsection{Moderate starvation test (T20/30)}

The total duration of this test was 2 hours, but the time during which cell 3 remained under gas starvation was 30 minutes. After this time, the valve of both gases was fully opened, passing again $100 \%$ of the stoichiometric flow. The results can be seen in Fig. 4 . Due to the starvation of reactant gases, the voltage of cell 3 slowly decreased by $16.4 \%$, from $0.725 \mathrm{~V}$ to $0.606 \mathrm{~V}$. However, when the nominal value of the flowrate for the two reactant gases was reestablished (minute 30 in the graph), the cell gradually recovered its optimal performance, generating a final voltage of $0.722 \mathrm{~V}$. So, it can be concluded that the effects caused by a moderate starvation of $\mathrm{H}_{2}$ (20\% of stoichiometric $\mathrm{H}_{2}$ flow) in a cell are reversible. Besides, the behavior of the rest of the cells was scarcely affected during the test. 


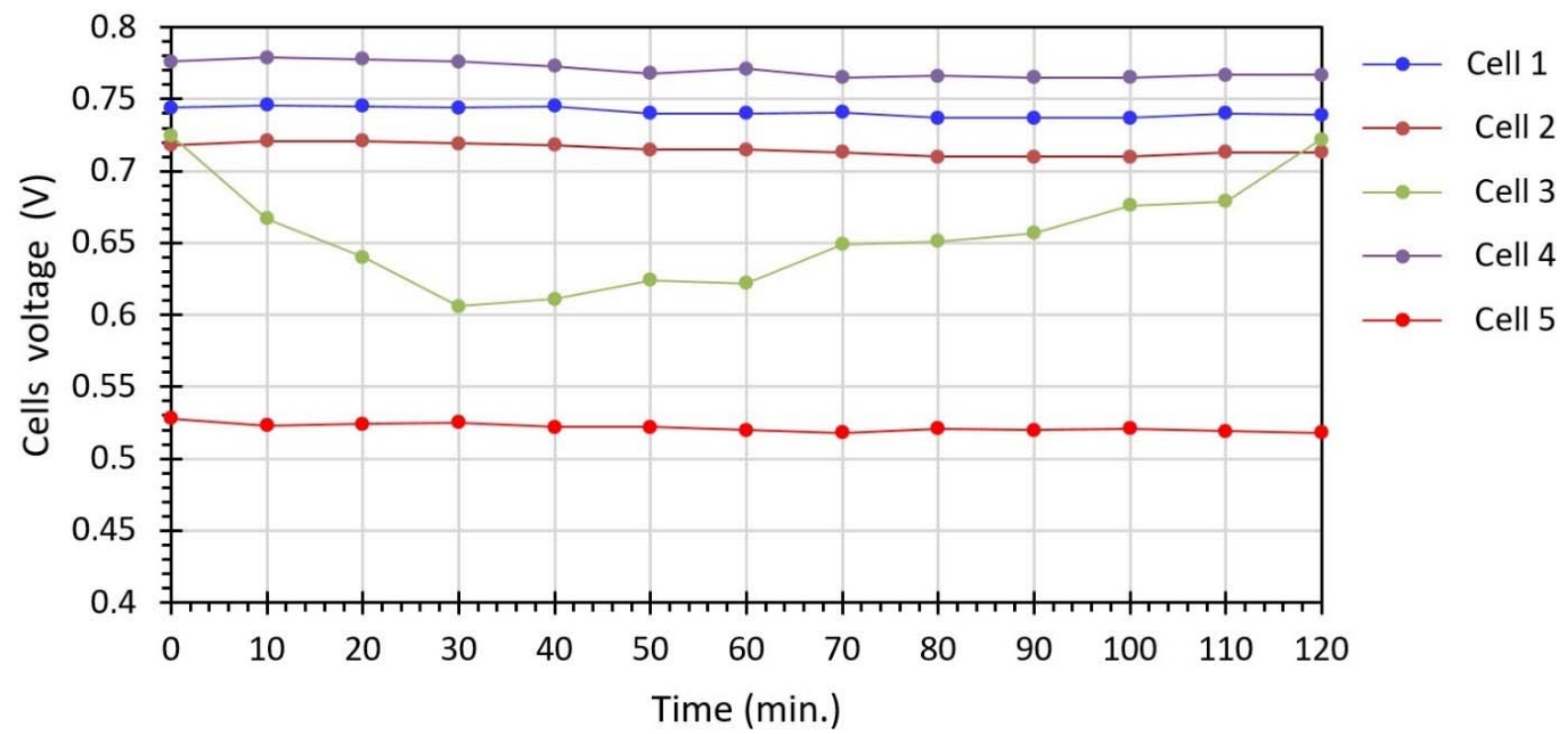

Figure 4. Variation of voltage with time obtained under T20/30 test in cell 3

For HT-PEMFCs with PBI membranes, the potential shift of the cell under gas starvation is due to the reduction of the hydrogen partial pressure over the catalyst surface, which reduces the mass transport and therefore the anode potential [56]. Simultaneously, the water produced in the cathode side diminishes, causing a decrease in the water partial pressure. Under these working conditions (low membrane humidity and high working temperature) the concentration of phosphoric acid $\left(\mathrm{H}_{3} \mathrm{PO}_{4}\right)$ is decreased because part of it is transformed into pyrophosphoric acid $\left(\mathrm{H}_{4} \mathrm{P}_{2} \mathrm{O}_{7}\right)$. The formation of different species of pyrophosphoric acid modifies the proton conductivity of the polymer and, therefore, the overall performance of the stack decreases. However, once the induced starvation stops and the nominal gas flowrate is restored, both the partial pressure of hydrogen over the catalyst layer and the production of water vapor in the cathode side are increased. So, water vapor is transported through the MEA to the anode side by the concentration gradient, reaching the optimal humidity degree in the membrane, and eventually improving its proton conductivity [57].

\subsection{Severe starvation test (T50/30 and $\mathrm{T} 50 / 120)$}

The results of the T50/30 test ( 30 minutes, $50 \%$ ) are shown in Fig. 5 . It can be seen that as soon as the gas flow was reduced to $90 \%$, the voltage of cell 3 dropped to $0.54 \mathrm{~V}$, while for $20 \%$ the voltage was limited to only $0.278 \mathrm{~V}$. This is a poorer performance than that measured the day before during the T20/30 test for the same gas flowrate limitation. This behavior could be due to the incipient degradation of this MEA caused by the gas starvation during T20/30 
test. For further flowrate reductions (to $70 \%, 60 \%$, and $50 \%$ ), the voltage of cell 3 became eventually inverted, reaching a final value of $-2.69 \mathrm{~V}$.

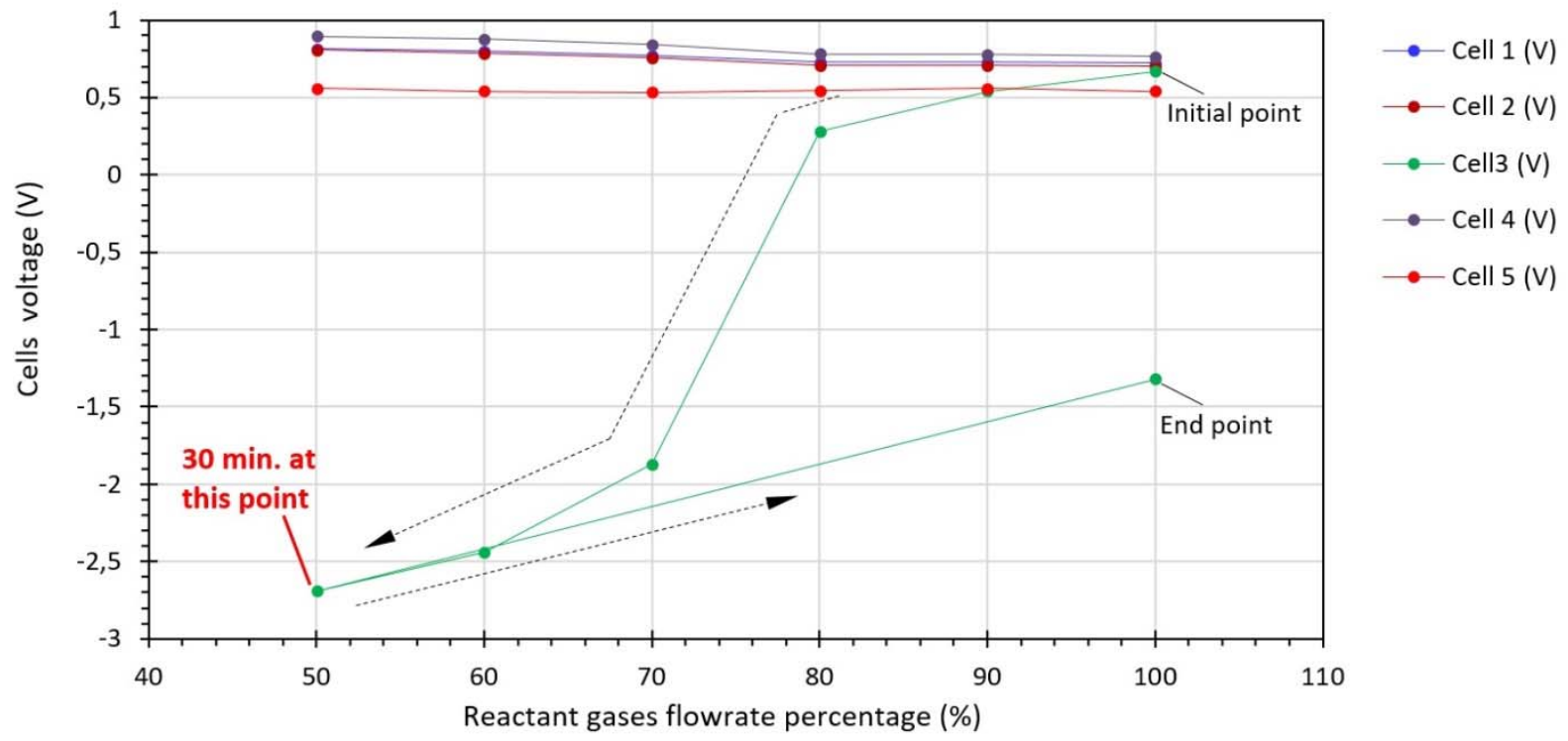

a)

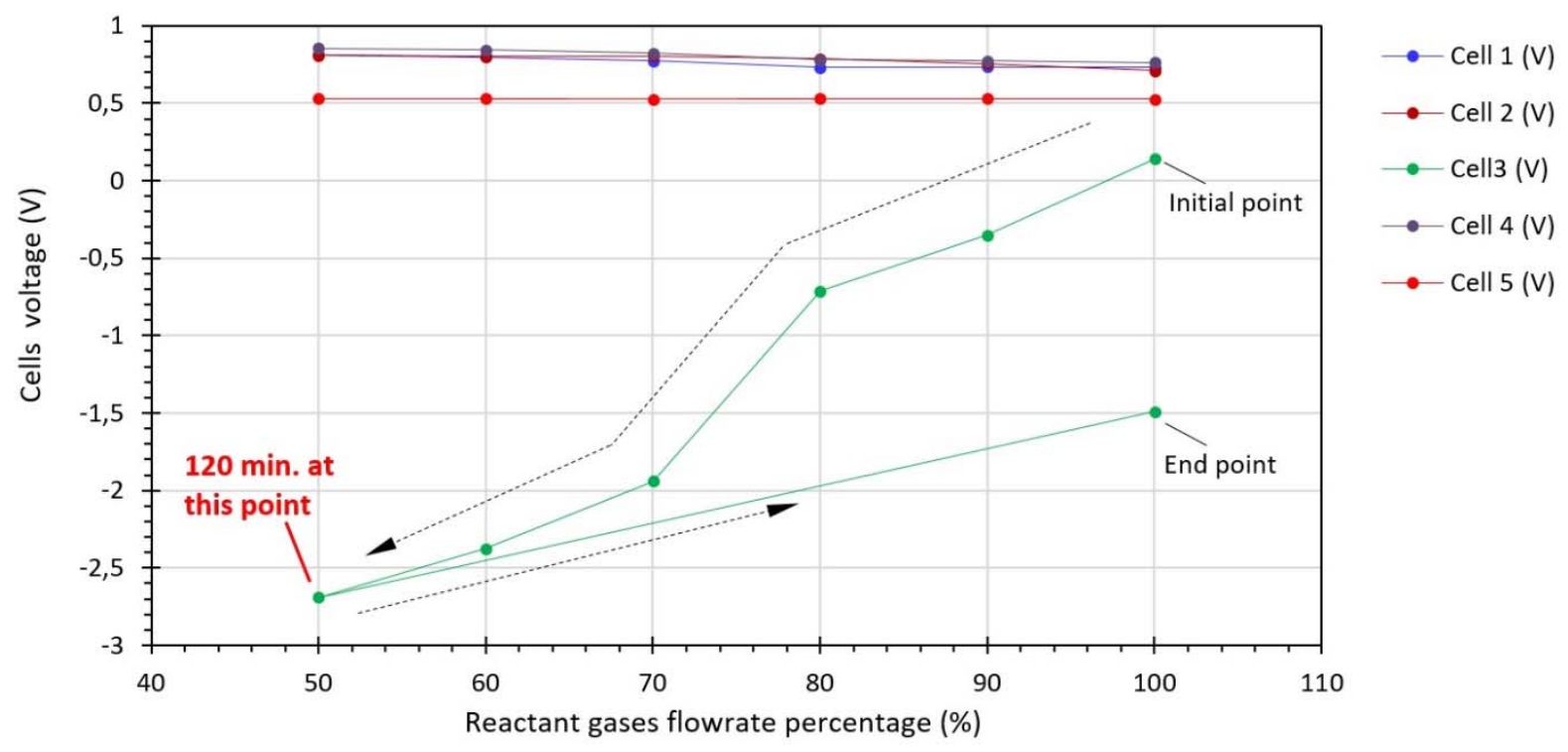

b)

Figure 5. Voltage yielded by the different cells under the experimental conditions for the severe starvation tests: a) T50/30; and b) T50/120

It is also notorious that the voltage produced by the rest of the cells was not affected. On the contrary, as the voltage produced by cell 3 decreased, the voltage generated by the rest of the cells slightly increased. This unexpected performance can be explained because the current produced by the stack was significantly reduced when the potential was inverted and, consequently, the voltages of the unaffected cells increased to match the one corresponding to the actual yielded current. For example, for $70 \%$ flow, the current value was reduced to 
$15.5 \mathrm{~A}$, for $60 \%$ it dropped to $8.72 \mathrm{~A}$, while with a flowrate of the reactant gases corresponding to $50 \%$ only $4.5 \mathrm{~A}$ were generated. In addition, when the flowrate of the reactant gases returned to $100 \%\left(0.25 \mathrm{NI} \mathrm{min}^{-1}\right.$ for $\mathrm{H}_{2}$, and $0.13 \mathrm{NI} \mathrm{min}^{-1}$ for $\left.\mathrm{O}_{2}\right)$, the voltage of cell 3 remained inverted $(-1.315 \mathrm{~V})$ and the current produced was limited to $18.6 \mathrm{~A}, 56.9 \%$ lower than the initial value (32.7 A).

Results obtained during the second severe starvation test T50/120 ( 2 hours at 50\% of the stoichiometric flowrate) show a similar trend to those in the first one, as depicted in Fig. 5b). Again, when the test was started the day after the first severe starvation test was performed, the initial voltage of cell 3 was only $0.142 \mathrm{~V}$. Afterwards, the cell voltage became inverted $(-0.352 \mathrm{~V})$ just limiting the flowrate to $90 \%$. When the flowrate was reduced to $50 \%$, the potential of this cell dropped to $(-2.69 \mathrm{~V})$, very similar to the value observed in the previous severe test. When the flowrate of the reactant gases returned to $100 \%$, the cell potential remained inverted at $-1.49 \mathrm{~V}$, and the current was reduced to only $15.6 \mathrm{~A}, 48 \%$ lower than the demanded value $(32.7 \mathrm{~A})$. When the starvation of hydrogen is induced in the anode, its voltage increases relative to the cathode one due to charging, eventually causing the voltage reverse in cell 3. Under this condition, the anode voltage becomes sufficiently large to drive the water electrolysis (i.e., the oxygen evolution reaction) and carbon corrosion reactions. Water electrolysis becomes the major reaction when the anode is at lower potentials during reversal, but it is deactivated in a short time and carbon corrosion continues to carbon dioxide $\left(\mathrm{CO}_{2}\right)$ or carbon monoxide $(\mathrm{CO})$, driving the cell voltage even more negative.

A very important result that should be highlighted is that the effects of the starvation on the central cell did not propagate to the neighboring ones. Actually, the voltage in the other cells of the stack slightly increased due to the limitation in the yielded current. So, it can be concluded that even when one of the MEAs has suffered irreversible degradation damages, the stack can still work, although with a severe current, and consequently power, decrease.

\section{4.- Steady-state tests}

The steady-state behavior of the 5 cells operating before and after the induced gas starvation events is summarized in Fig. 6 . The break-in procedure followed for all these tests was the same as that discussed in Section 3.1. The x-axis of Fig. 6 intentionally starts in time $t_{0}=400$ min., in order to ease the discussion of the main results obtained. During the initial tests at steady-state conditions (until $\mathrm{t}=810 \mathrm{~min}$ ) it was verified that both the stack as a whole and all 
the individual cells behaved very stably. It was also confirmed that this behavior remained constant in time, as long as no irreversible degradation damages were induced in any cell, such as those caused in T50/30 starvation test (flow reduction of 50\% during $30 \mathrm{~min}$.). It was verified that the performance of cell 3 slightly worsened after performing the induced moderate T20/30 starvation test, from an average voltage of $0.71 \mathrm{~V}$ during initial steady-state test decreasing to $0.685 \mathrm{~V}$ after T20/30. At the same time, the voltage produced by the remaining cells was slightly improved.

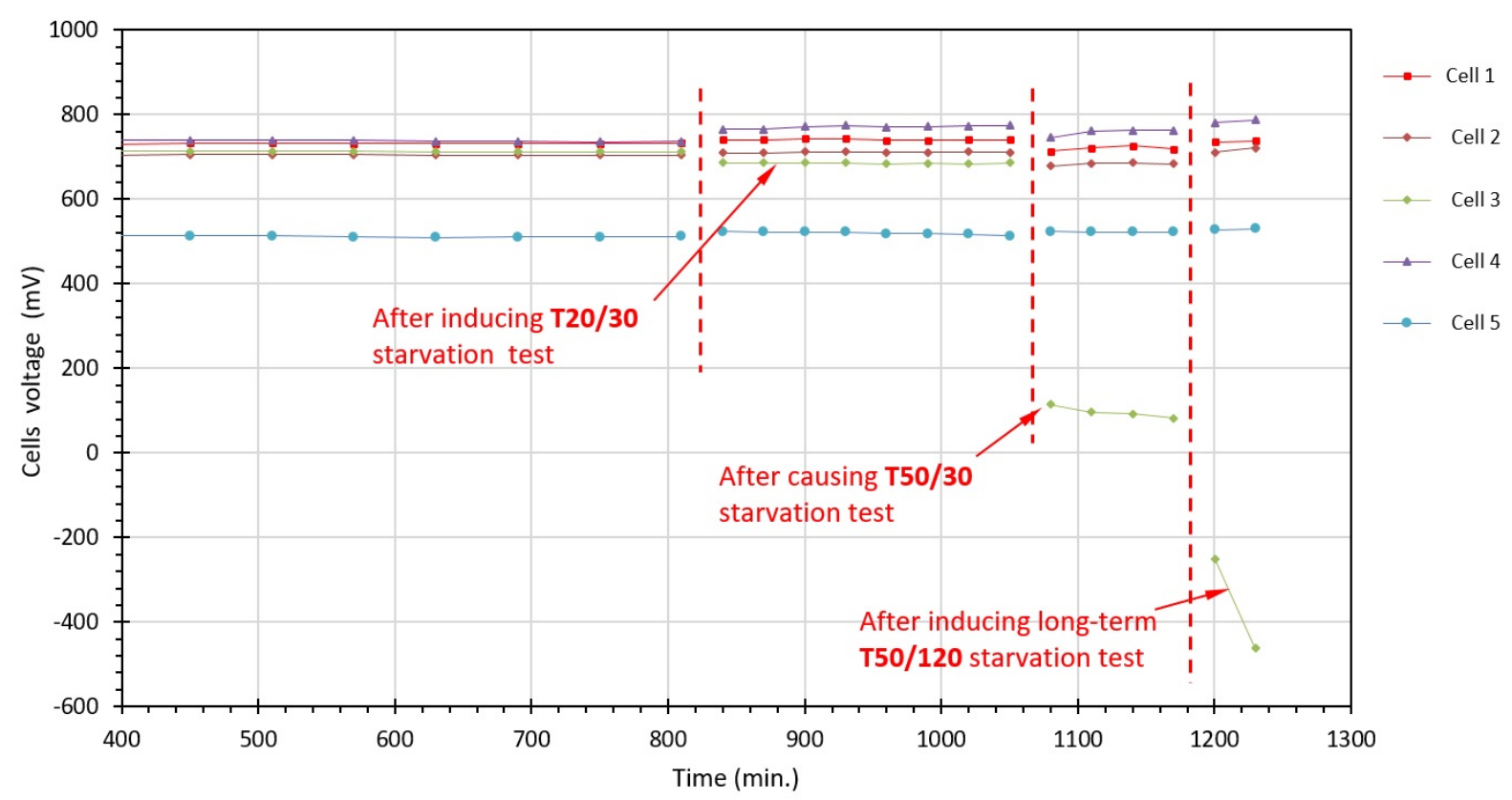

Figure 6. Voltage variation with time of the different cells during starvation tests

As expected, the performance degradation of the cell 3 after inducing the severe T50/30 starvation test of the reactant gases was clearly evident, as depicted from time $840 \mathrm{~min}$. to $1050 \mathrm{~min}$. in Fig. 6. However, it should be noted that the potential of the affected cell (\#3) was higher at the beginning of the steady-state test $(0.12 \mathrm{~V})$ when compared to the final voltage obtained after the induced $\mathrm{T} 50 / 30$ severe starvation test ( $-1.32 \mathrm{~V}$, see Fig. $5 \mathrm{a}$ ). A similar result was verified at the start of the steady-state test after the second severe T50/120 starvation test ( 2 hours at a flowrate reduced 50\%). In this case, the voltage at the beginning of the steady-state test after inducing the T50/120 starvation test was limited to $-0.245 \mathrm{~V}$, when at the end of the T50/120 test it was only of $-1.49 \mathrm{~V}$. The potential improvements compared to the final voltage reached during the severe starvation tests (T50/30 and T50/120) could be explained by the suitable conditioning of the MEA during the start-up procedure before performing the steady-state tests. In any case, the intense degradation of the MEA of cell 3 
after the T50/120 starvation test restricted the steady-state operation to only two experimental points. The stack was halted for safety reasons due to the strong potential inversion in that cell. It can be concluded that the damages caused to the MEA by an aggressive gas starvation, which is also maintained in time, are irreversible.

\section{5.- Average temperature}

To complete the analysis, the average temperature of the different BPPs was measured by infrared thermography. Although probably it is not the ideal measuring method to determine local temperature, an increase in the average value could indicate a defective cell operation. Using the control software of the FLIR T-200 camera, measurement points were located on each plate, identified as spots 1 to 6 in Fig. 7a). Spots 9 and 10 in the photo correspond to the temperature of the cathode and anode endplates, respectively. Average temperature values measured during the "moderate starvation" test are shown in Fig. 7b). It should be noted that the temperature reported for cell 1 corresponds to the average value between plates 1 and 2 , that of cell 2 to the average between plates 2 and 3 , and so on.

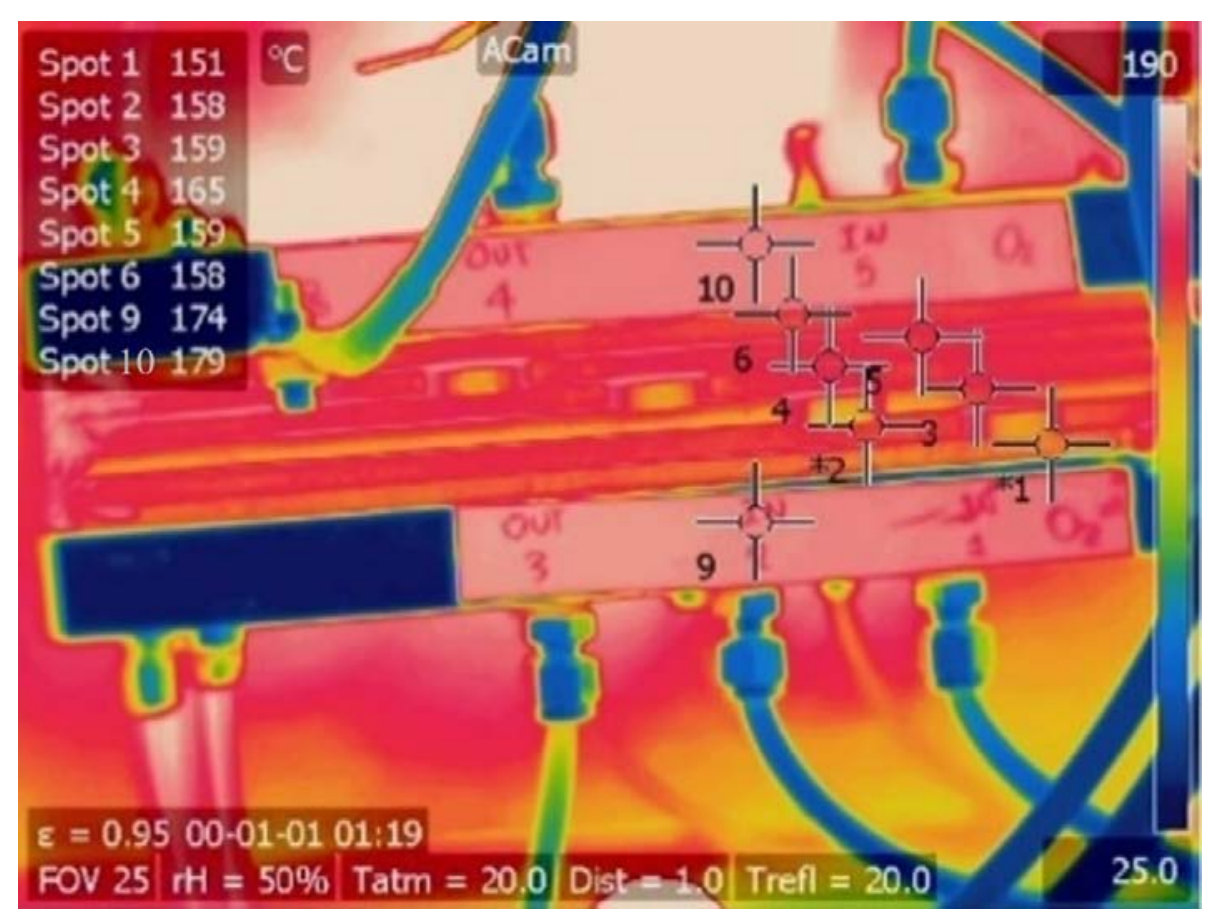

a) 


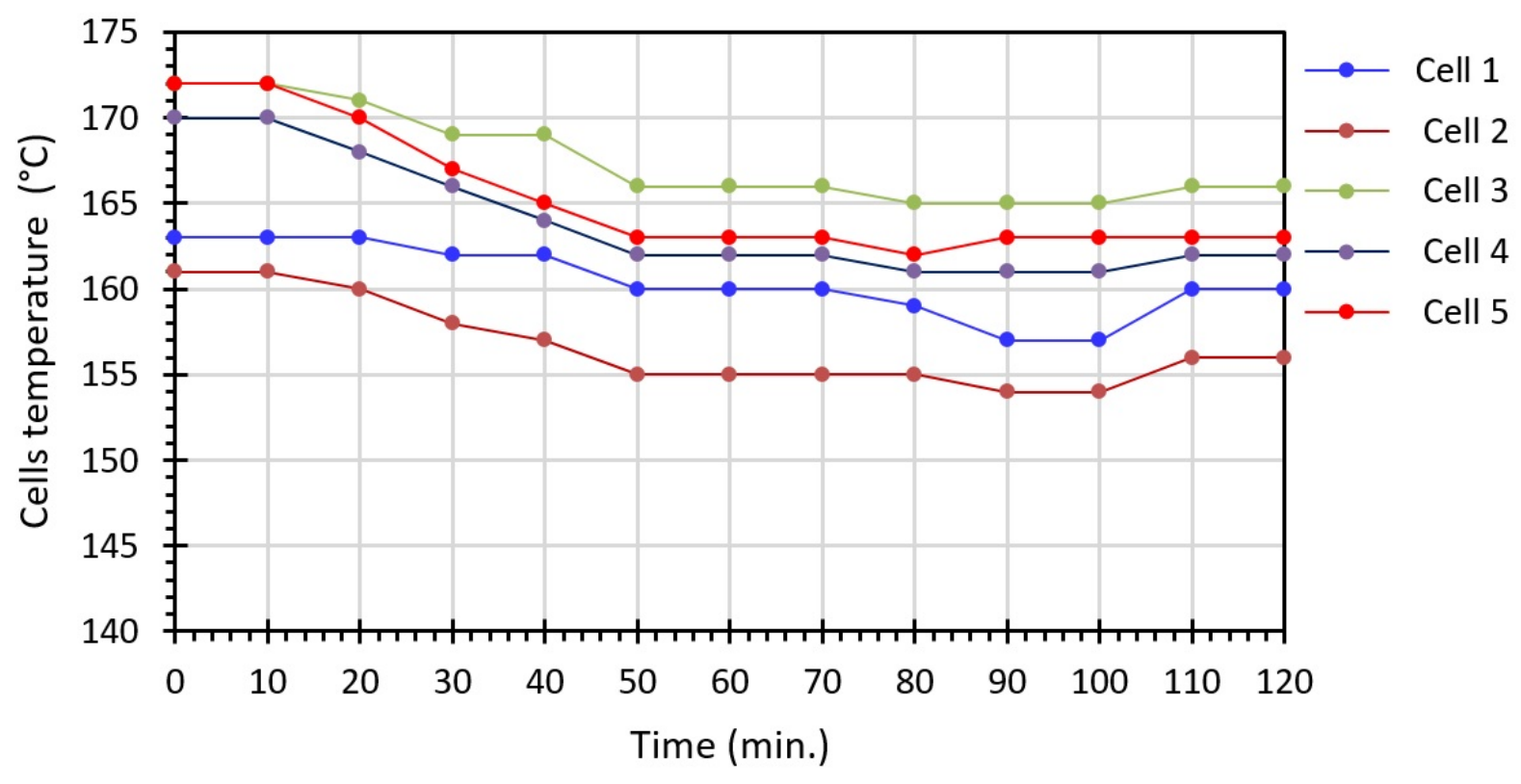

b)

Figure 7. Infrared termography measurement of the average temperature of the cells (a) and measured values during the "moderate starvation" test (b)

Although in this test the damages induced by the starvation were reversible, cell 3 was the hottest reaching average values close to $170^{\circ} \mathrm{C}$. For the severe starvation test $(\mathrm{T50} / 120)$ the increase in local temperature measured in cell 3 with a $\mathrm{K}$-type thermocouple was around $30^{\circ} \mathrm{C}$, exceeding $190^{\circ} \mathrm{C}$. Under this situation, the cell working temperature exceeded the optimal range suggested by $\mathrm{DPS}\left(150^{\circ} \mathrm{C}-170^{\circ} \mathrm{C}\right)$, resulting in a drastically reduced MEA proton conductivity due to the evaporation of the free phosphoric acid, and eventually causing a decrease in the stack performance, as was verified in the test.

Results obtained indicate that partial or complete hydrogen starvation at the anode sides is a critical challenge that still needs to be solved to ensure robust PEMFCs. Working under this condition induces the cell potential inversion, causing a significant heat production that can alter the MEA structure, and to create pin-holes in the membrane eventually resulting in catastrophic cell failure. To verify some of these points a post-mortem analysis of the affected MEAs has to be performed.

\section{6.- Post-mortem analysis of the membrane electrode assemblies (MEAs)}

A visual evaluation of the different MEAs was performed once the stack was disassembled. It was confirmed that no evident damages were observed in the MEAs of cells $1,2,4$ and 5 . However, the MEA in cell 3 showed clear damages. As displayed on Fig. 8a), it was verified 
that on the GDL of the anode side there were some scorched zones indicative of a harmful increase in local temperature. Residues from the calcined GDL from these zones were also found on the ribs of the flowfield geometry of the graphite bipolar plate (BPP). Evidences of the excessive local temperature values reached in the damaged zones are the perforations detected in the GDL of the anode side, as shown in Fig. 8b). They were observed when the GDLs were separated from the polymeric membrane. On the other hand, orifices were not observed neither in the membrane nor in the GDL of the cathode electrode. The orifices in the GDL suggest that the local temperature values reached in the damaged area during the starvation experiments were probably greater than the average temperatures measured by infrared thermography. This hypothesis is in good agreement with several previous studies performed on the temperature fields in PEMFC stacks using both experimental techniques and numerical simulation methods [59-64]. Using a K-type thermocouple, it was detected that the temperature is non-homogeneously distributed, having a maximum in the central zone of the cells. The non-uniform temperature distribution can be attributed, among other factors, to the high concentration of water in the areas where perforations were detected, and to the uneven distribution of reactant gases. In fact, the local temperature distribution can reveal a deficient local dynamic performance of the PEMFC, which can cause the failure of the thermal management strategy and the degradation of the stack.

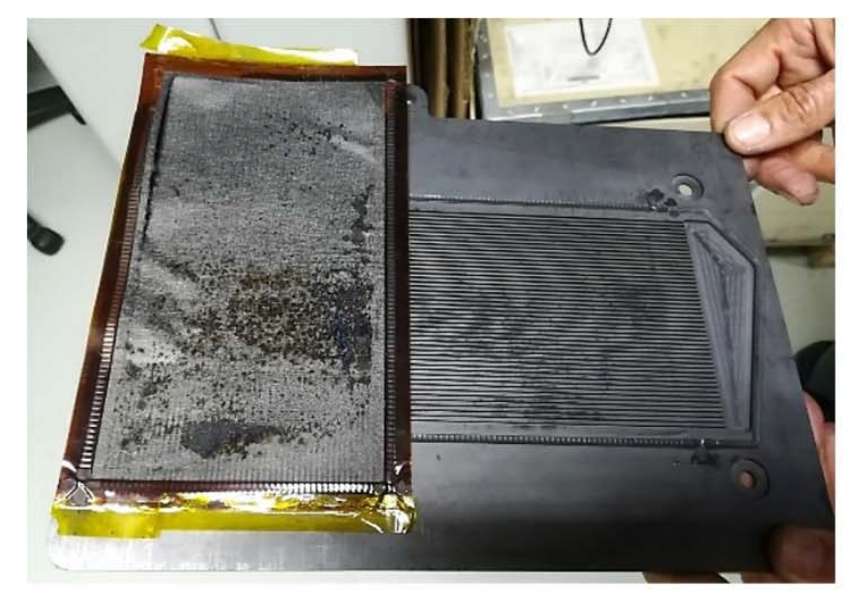

a)

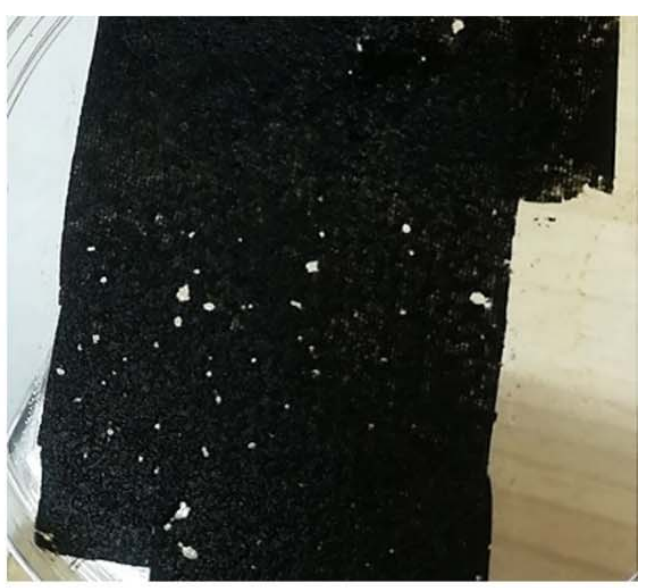

b)

Figure 8. Damages observed in the elements of the MEA used in cell 3 after starvation tests

Different areas of the MEAs of cells 1, 3, 4 and 5 were studied by SEM-EDX, in order to evaluate their morphological features after operation. These post-mortem studies served to understand the anomalous behavior of cell 5 and the damages caused by the induced reactant gases starvation in cell 3 . Besides, the MEA in cell 4 was also analyzed in order to check 
whether local damage to cell 3 could have also degraded neighboring cells. Moreover, an unused (fresh) MEA that could serve as a reference to the main conclusions was also analyzed. The sections chosen for each MEA were selected from the most interesting or representative regions.

As can be seen in Fig. 9, no notable differences are observed between the photos of the "fresh" MEA (Fig. 9a)) and that of cell 1 (Fig. 9b)). Therefore, it can be concluded that when a MEA works correctly (MEA 1), its morphology does not change in the extent detectable by SEM. Analyzing the photos of Figs. 9c) to 9e), which correspond to two different areas of the MEA of cell 3, it can be seen that the damages caused by the starvation experiments are catastrophic. The different layers are clearly separated, and the thickness of the catalyst layer of the anode side has thinned significantly. Furthermore, the polymer of the membrane is calcined, appearing somehow crystallized. These results could be explained by the high local temperatures reached in that area. The delamination between the membrane and the catalytic layers of both electrodes can be also caused by the migration of the $\mathrm{H}_{3} \mathrm{PO}_{4}$ during the first hours of operation of the stack and by the induced reactant gases starvation in the stack. Acid migration causes a gradual decrease in the $\mathrm{pH}$ of water, which could be one of the possible reasons for the increase in the resistance of the charge transfer verified in PEMFCs [65].
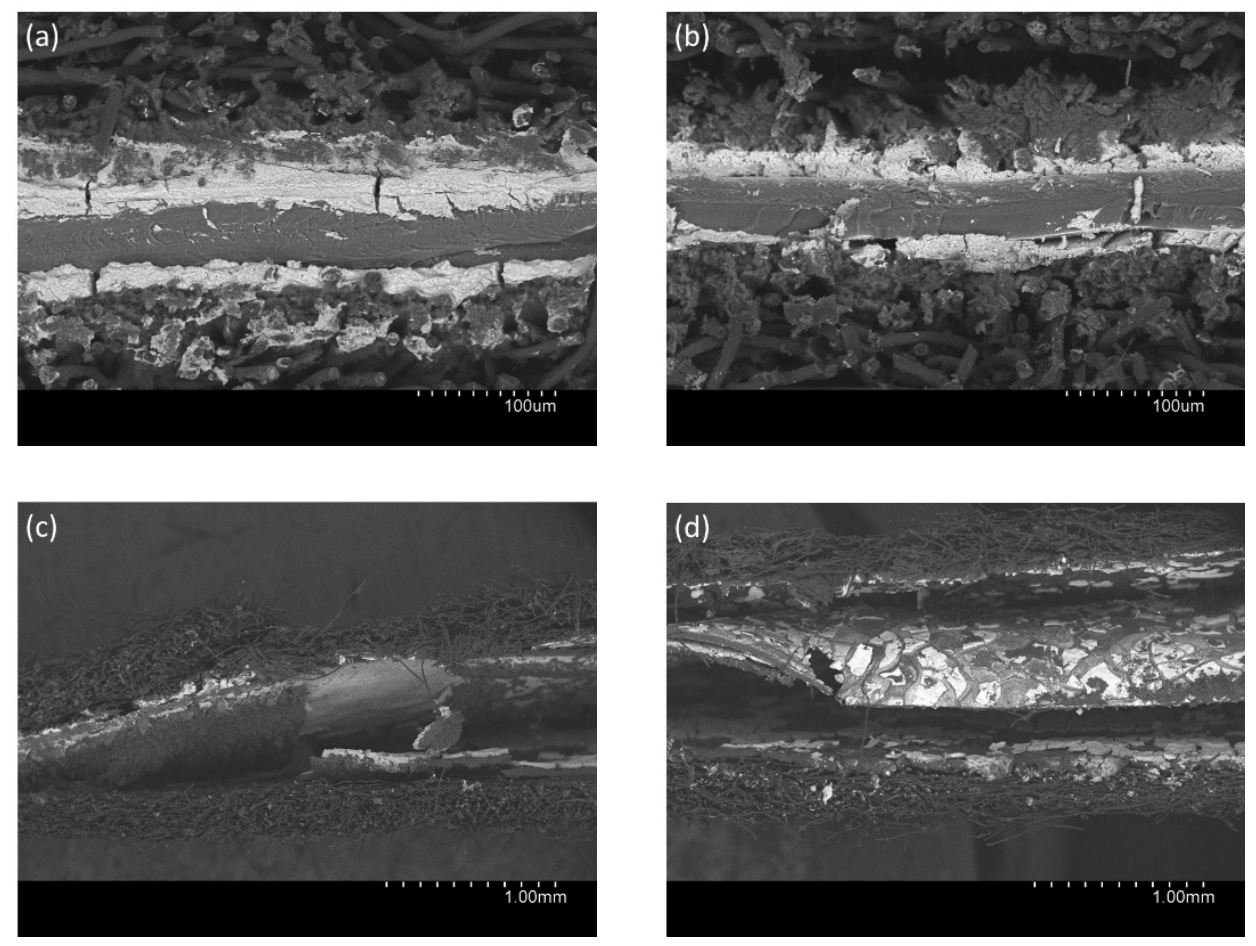

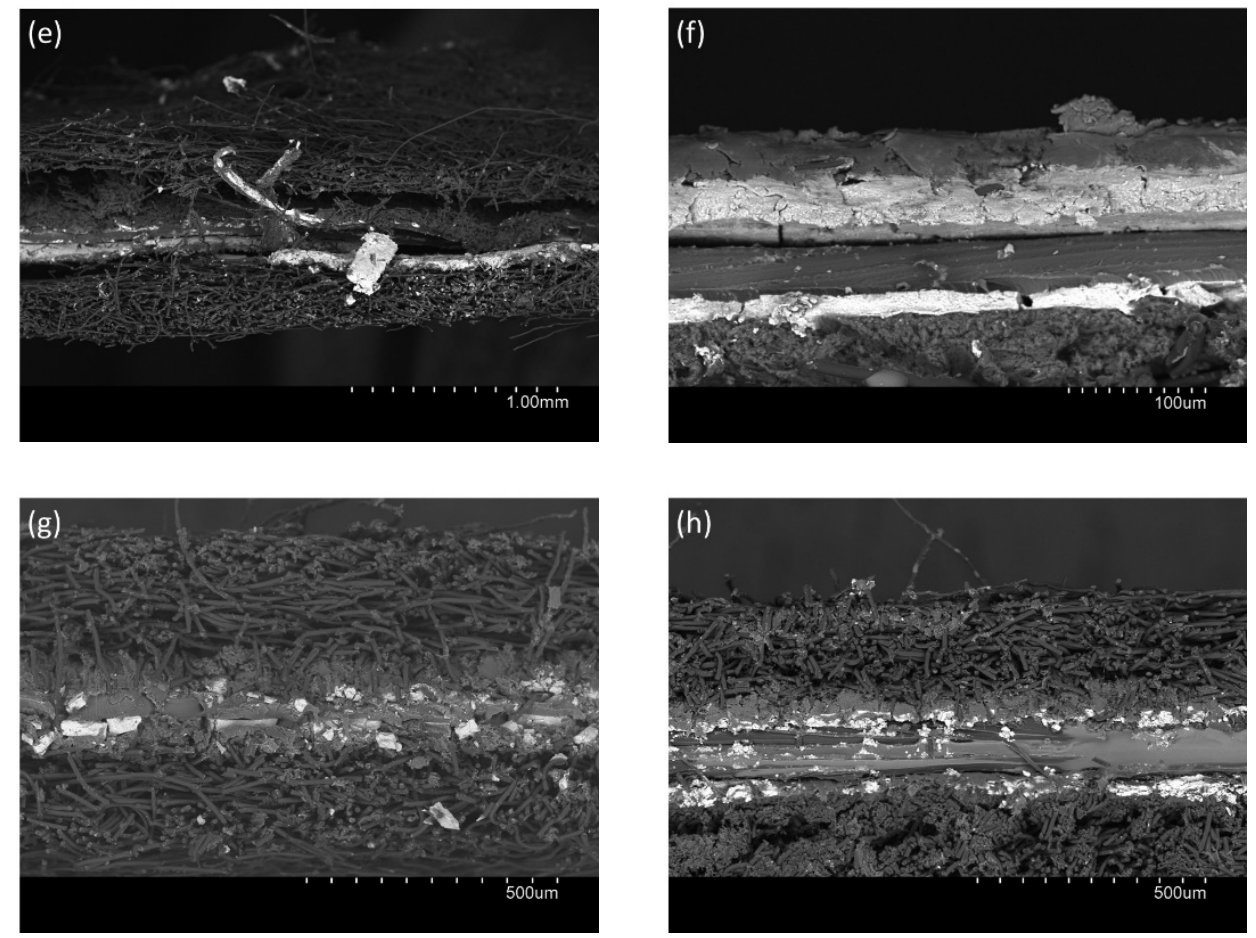

Figure 9. SEM images at different magnification of cross-sectioned-MEAs (anode on the upper part of each image, cathode at the bottom part of the images): (a) unused (fresh) MEA (b) MEA of cell 1, (c to e) MEA of cell 3, (f) MEA of cell 4 and ( $g, h$ ) MEA of cell 5.

From the SEM image in Fig. 9f) it can be concluded that, although the MEA from cell 4 is one of the neighbors of the central one (cell 3) that was exposed to the induced gas starvation tests, it does not show any appreciable damage. There is an area where the layers seem to be slightly separated, but since this cell always worked correctly, these damages could be attributed to the sample preparation process. Photos in Fig. 9g) and 9h), corresponding to the MEA of cell 5, show significant damages in the membrane. It is difficult to assure if these damages had their origin in the manufacturing process or if they were a consequence of the stack operation. However, these results could explain why the voltage produced by this cell was initially lower than that of the other cells.

SEM-EDX analysis, performed on the studied MEAs (both in the catalyst layers and the membrane), also showed interesting results. Some of them are depicted in Fig. 10 (a-d for the MEA from cell 1 and in Fig. 10 (e-f) for the MEA from cell 3). A small concentration (5.3 wt. \%) of phosphorus was detected in the catalyst layer $(\mathrm{CL})$. This result shows that the phosphoric acid is expelled from the MEA polymer due to the increase in relative humidity caused by the water produced by the electrochemical reaction inside the stack. Presence of fluorine at the cathodic CL (Fig. 10d) was also observed, probably due to the use of PTFE as binder when forming the catalytic ink. On the other hand, and as expected, in the zone of the polymeric 
membrane (Fig. 10c) only phosphorus, carbon and oxygen were detected.
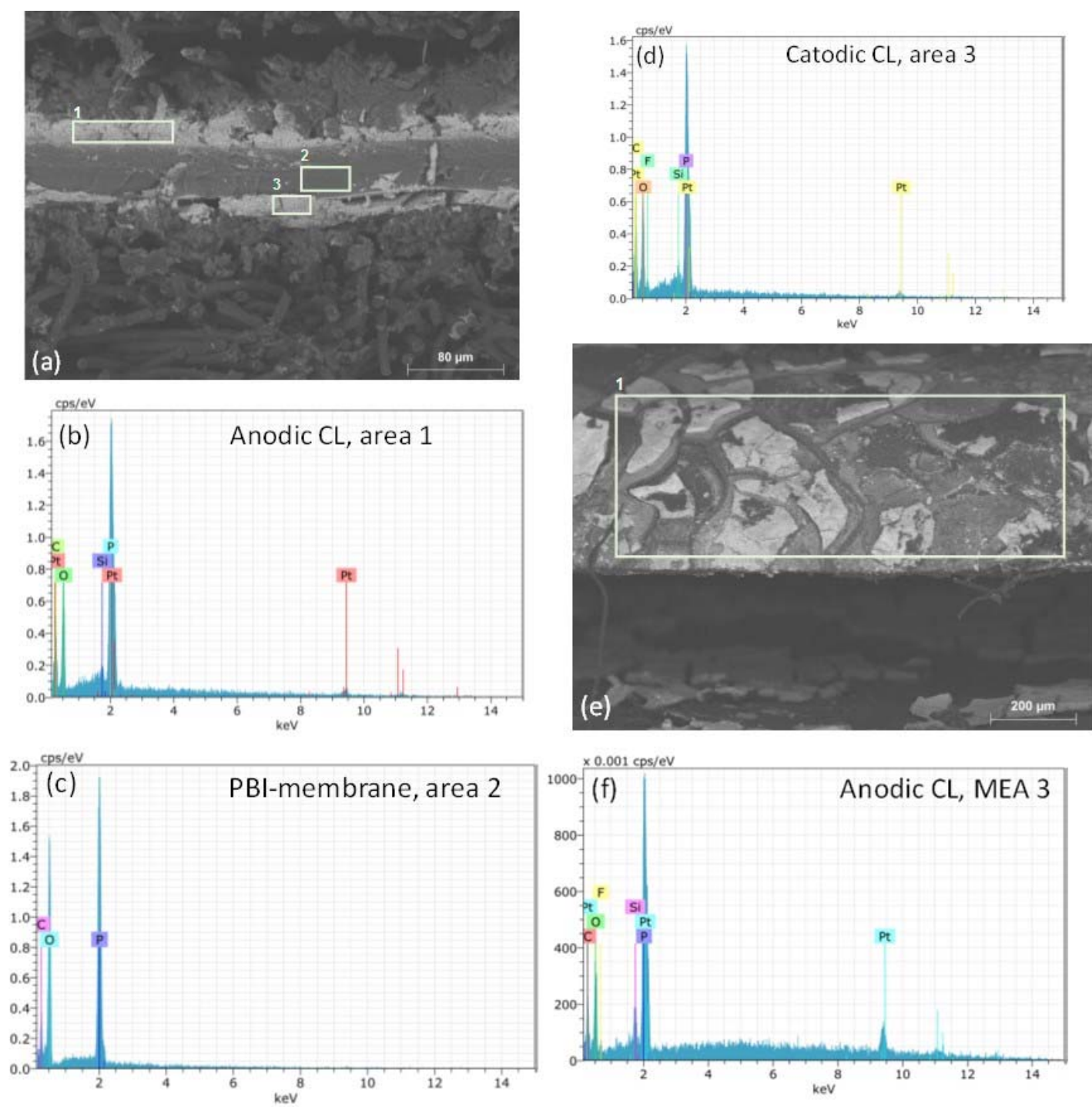

Figure 10. Post-mortem analysis by SEM-EDX of the catalytic layers (CLs) and the membrane of the MEAs from cell 1: (a) cross-section image, (b) EDX analysis of the anodic CL, (c) EDX analysis of the PBI-membrane and EDX analysis of the cathodic CL; cell 3: (e) cross-section image, (f) EDX analysis of the anodic $C L$.

A similar composition was observed for the analysis performed to the MEA of cell 3 after the different tests. Only phosphorus, carbon and oxygen were detected in the polymeric membrane, while the presence of phosphorus (probably expelled from the polymer) and fluorine (from the PTFE used in the catalytic inks) was confirmed in the CLs. In this case, the quantified phosphorus percentage was around $11 \%$ wt. for the MEA. 


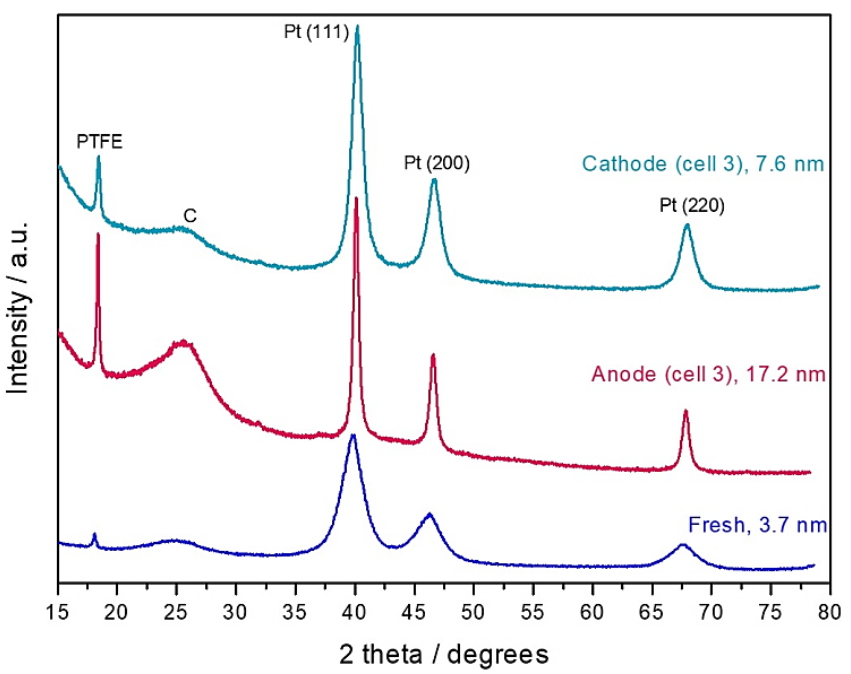

Figure 11. XRD diffraction patterns for the fresh MEA (prior to use) and both anode and cathode from cell 3 after the starvation tests.
Table 1. Crystallite size calculated from the XRD diffraction patterns applying the Scherrer's law.

\begin{tabular}{lc}
\hline Sample & $\begin{array}{c}\text { Crystallite size } \\
\text { / nm }\end{array}$ \\
\hline Anode cell 1 & 8.0 \\
Cathode cell 1 & 6.5 \\
\hline Anode cell 2 & 7.6 \\
Cathode cell 2 & 6.8 \\
\hline Anode cell 3 & 17.2 \\
Cathode cell 3 & 7.6 \\
\hline Anode cell 4 & 6.7 \\
Cathode cell 4 & 7.2 \\
\hline Anode cell 5 & 7.7 \\
Cathode cell 5 & 7.4 \\
\hline
\end{tabular}

Pt catalysts grafted from both the fresh and used MEAs (after the starvation tests) were analyzed by X-Ray diffraction. Figure 11 shows the XRD pattern for the fresh catalyst (either anode or cathode) and both anode and cathode from cell 3, where the typical reflections of the Pt face cubic centered (fcc) structure are observed. Reflections from C (at $26^{\circ}$ ) and PTFE $\left(\right.$ at $18^{\circ}$ ) are also observed. PTFE was probably employed as binder in the preparation of the ink for the electrode. The strong degradation caused by the starvation tests is particularly evident in the diffractogram for the anode and cathode of cell 3, showing more intense and narrow Pt peaks in comparison to the fresh electrode. Crystallite sizes were calculated by Schrerrer's law [55]. Catalysts in both anode and cathode sides on the fresh MEA (prior to use) present Pt crystallites around $3.7 \mathrm{~nm}$. After operation of the stack, Pt crystallite size increases in all the MEAs due to the degradation suffered during operation, as shown in Table 1. In general, the crystallite size for both anodes and cathodes almost doubles after the stack operation, being more evident in the case of the anode $(7.5 \mathrm{~nm}$ medium crystallite size versus $7.0 \mathrm{~nm}$ medium crystallite size for the cathode). The anode from the starved cell, cell 3, presents a great enlargement of the Pt crystallite size: $17 \mathrm{~nm}$ (4.6 times the original size), whereas the cathode, keeps the same trend as the other cells $(7.6 \mathrm{~nm})$. This confirms that the starvation of hydrogen entails a more aggressive degradation for the catalyst, due to the known water electrolysis and carbon corrosion suffered when potential in the anode rises [37]. 
XRD results were corroborated by transmission electron microscopy. These analyses revealed interesting insights on the degradation of MEAs, particularly, from the starved cell 3. Figure 12 shows TEM images obtained from the powders scratched from the MEAs. Figure 12a) and 12b) show TEM images at low and high magnification of the fresh MEA (as received and prior to any experiment) in order to obtain a representative idea of the distribution of Pt particles on a fresh electrode. As ascertained from the images, $\mathrm{Pt}$ is well distributed throughout the carbon support, with particles with an average size around $3 \mathrm{~nm}$. In general, catalysts grafted from MEAs of cells 1, 4 and 5 are similar (Figs. 12c) to 12h)). All of them show areas with both agglomerated and well-distributed particles, as well as areas of the carbon support without Pt particles (that probably have dissolved and re-precipitated due to Ostwald ripening caused by operation).
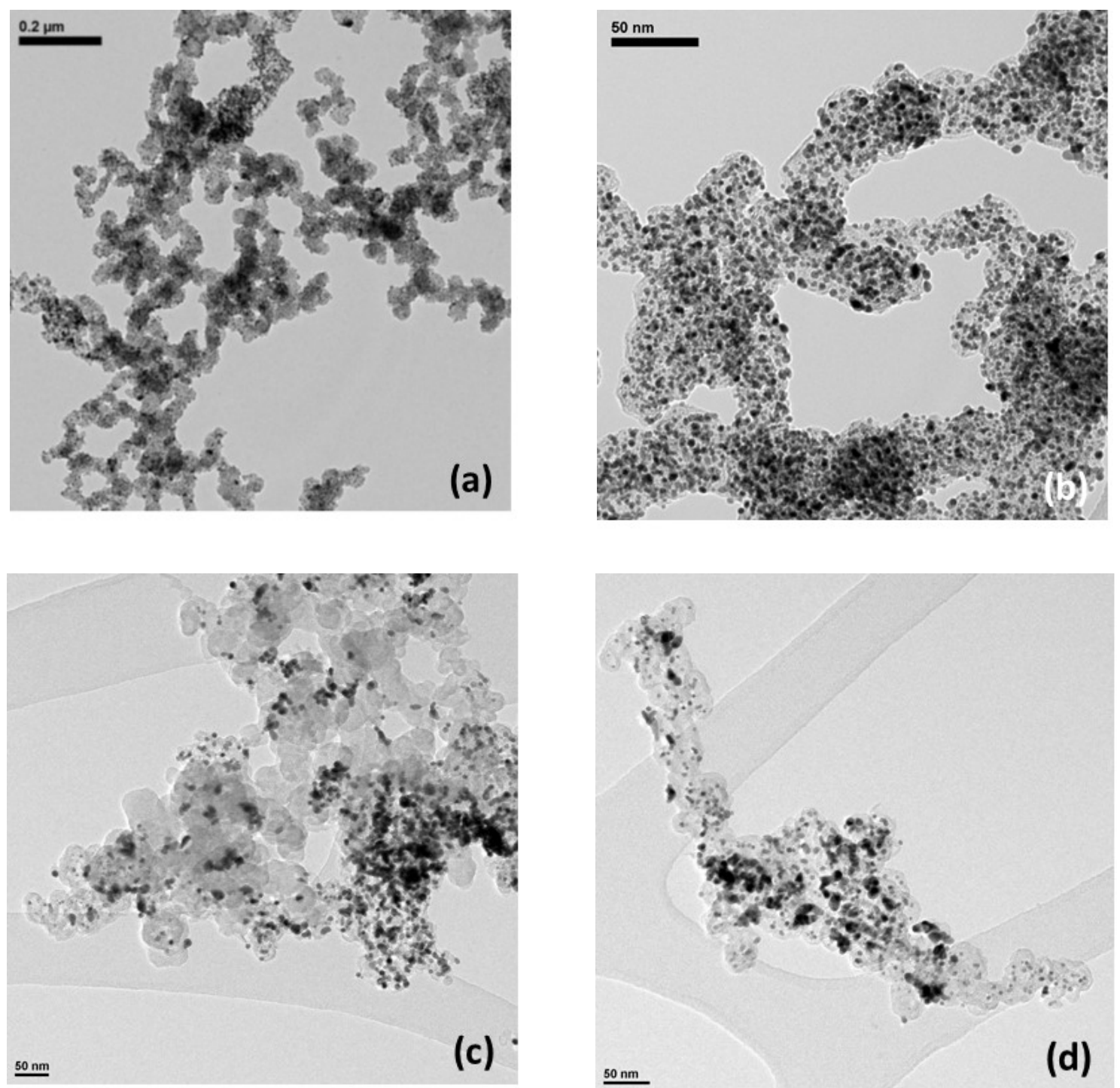

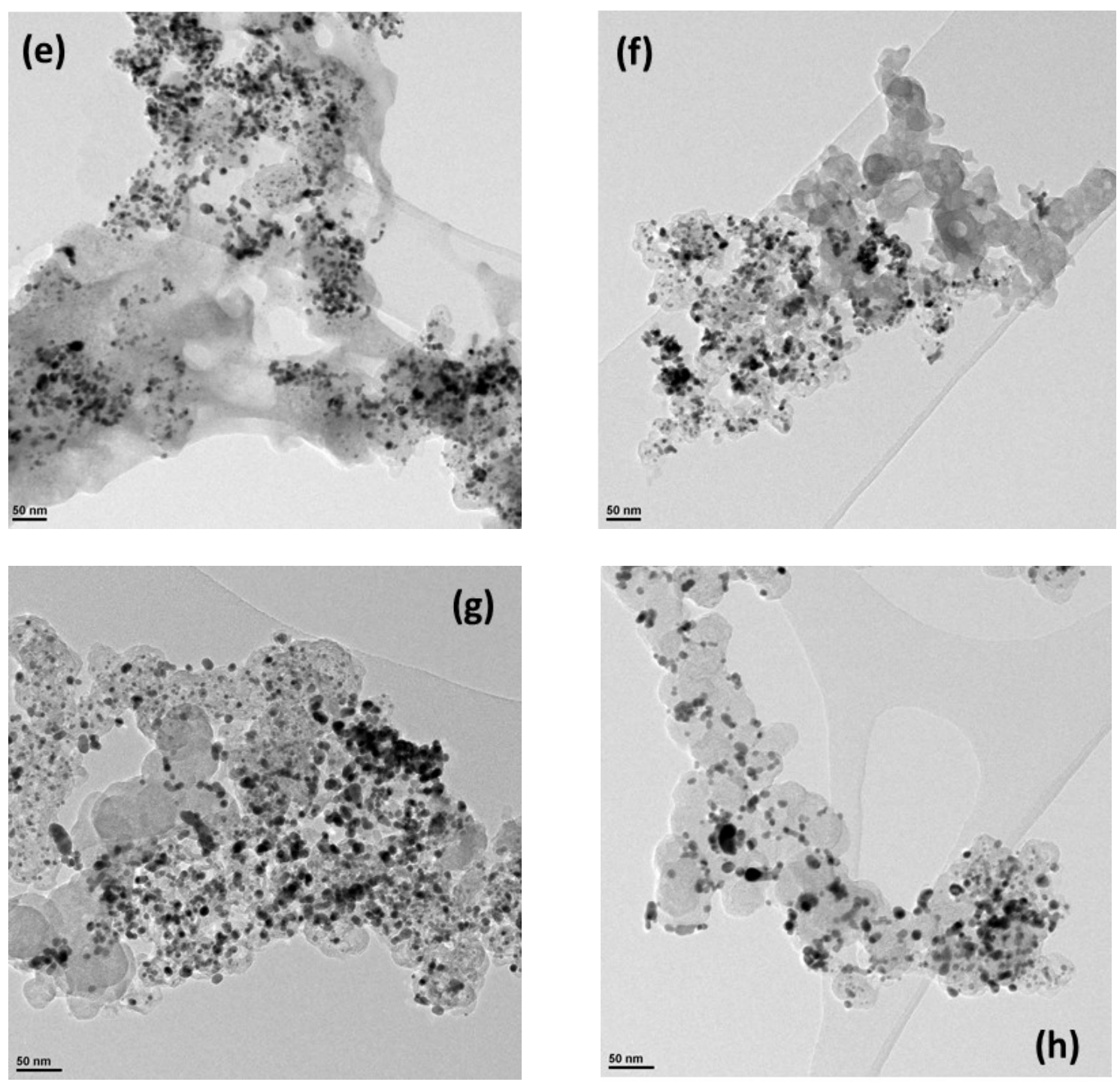

Figure 12. TEM images for catalysts grafted from the MEAs before and after the starvation tests: (a), (b) from the fresh MEA (prior to use); (c) anode from cell 1, (d) cathode from cell 1; (e) anode from cell 4, (f) cathode from cell 4; (g) anode from cell 5 and $(h)$ cathode from cell 5 . Scale bar $=50 \mathrm{~nm}$.

Figure 13 shows the images of the catalysts obtained from cell 3 after the starvation tests. Images in Fig. 13a) to 13c) show the anode side. Figure 13a) shows small Pt particles isolated in the carbon support that presents a degraded aspect. These small particles might be pieces of bigger particles that have dissolved and re-precipitated in another area of the catalyst. Figure 13b) shows a large area of carbon support without Pt particles, and an agglomerate (12-17 nm size) of Pt particles. Figure 13c) shows a lower magnification image in which we can see areas of the carbon support without Pt particles, and areas with a great agglomeration of metallic particles. As expected from the visual inspection of the MEA from cell 3 and from the XRD results, the anode side of the MEA has suffered a major degradation. On the other hand, the cathode side (Figs. 13d) and 13e) shows a similar aspect than the previously shown 
catalysts from neighboring cells. The cathode of cell 3 presents areas showing agglomeration of Pt particles, but still maintaining a good particle distribution.
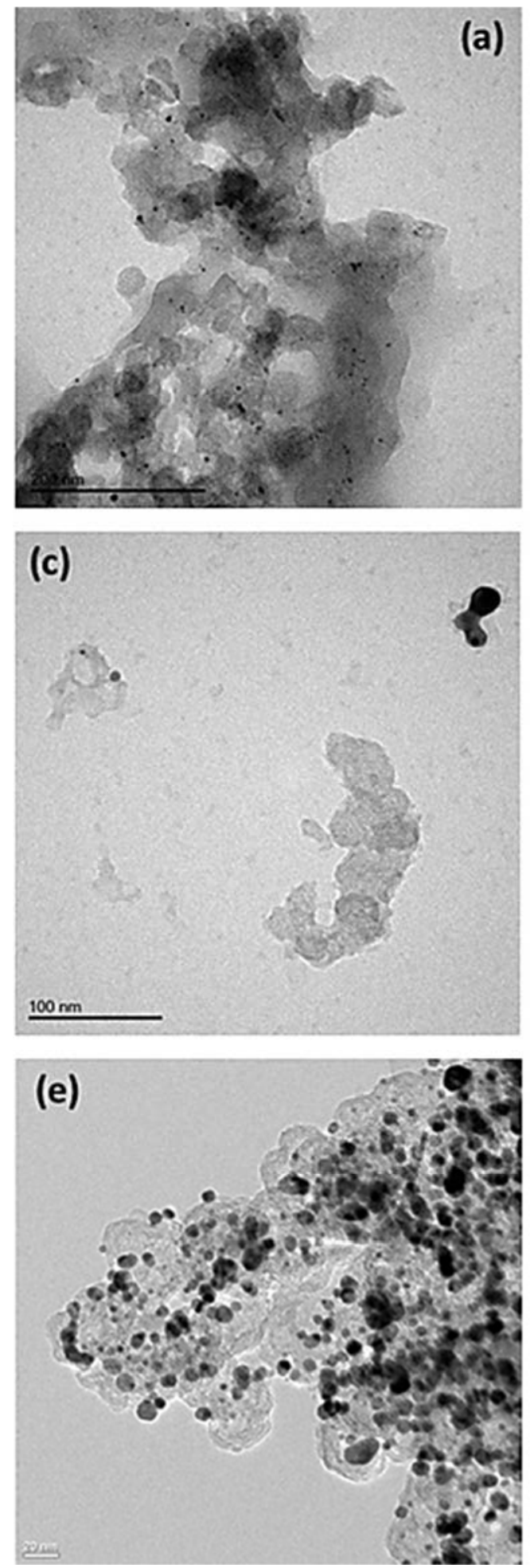
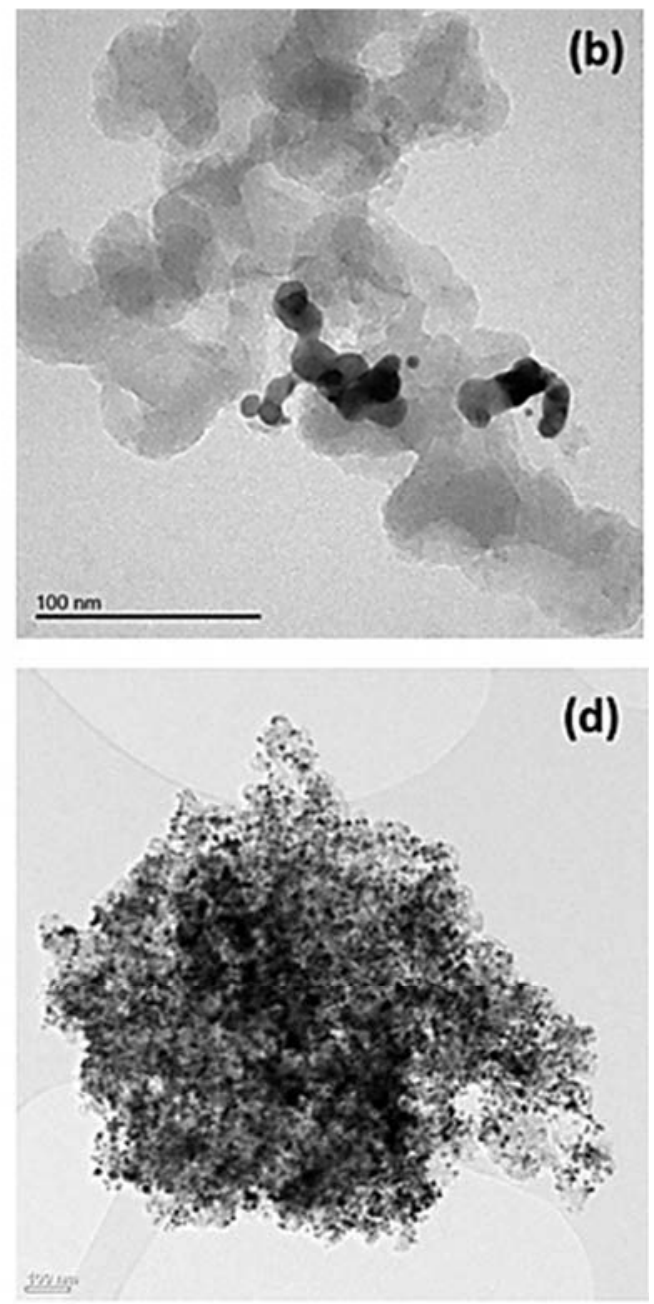

Figure 13. TEM images for catalysts grafted from the MEAs for cell 3 after the starvation tests: (a), (b) and (c) anode side; (d) and (e) cathode side. Scale bars: (a) $200 \mathrm{~nm}$ (b), (c), (d) $100 \mathrm{~nm}$ and (e) $20 \mathrm{~nm}$.

Figure 14 shows the normal distribution obtained from the histograms of the TEM images previously shown. The diameter of more than 300 particles per sample was measured in order 
to obtain a representative distribution. Figure 14a) shows the comparison between both the cathode and anode sides. It is evident (as also corroborated by XRD) that the cathode side has maintained a lower mean particle size in comparison to the anode side. For clarity reasons, the graph has been split into two, showing the normal distribution for the cathode (Fig. 14b) and the anode (Fig. 14c) separately. Cathode shows a main peak centered around $5 \mathrm{~nm}$, whereas the anode shows peaks centered between 5 and $10 \mathrm{~nm}$, and in the case of cell 3 , with a bimodal distribution with two peaks: one centered at $6 \mathrm{~nm}$ and the other around $15 \mathrm{~nm}$.

(a)

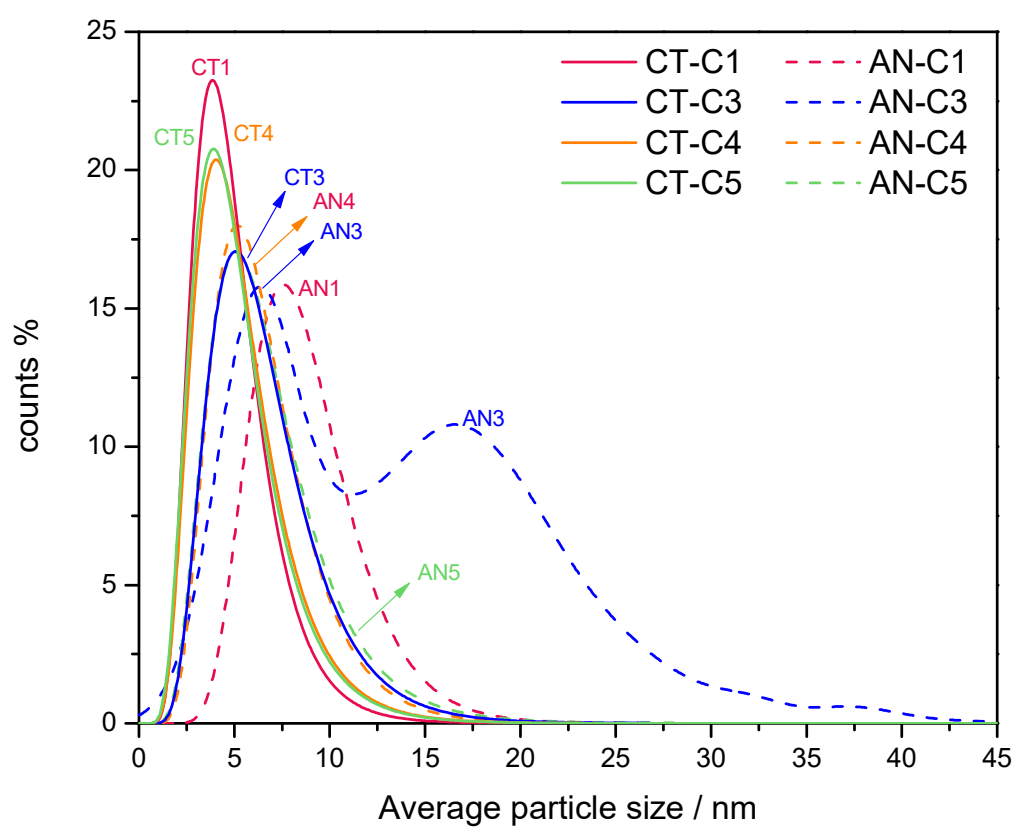

(b)

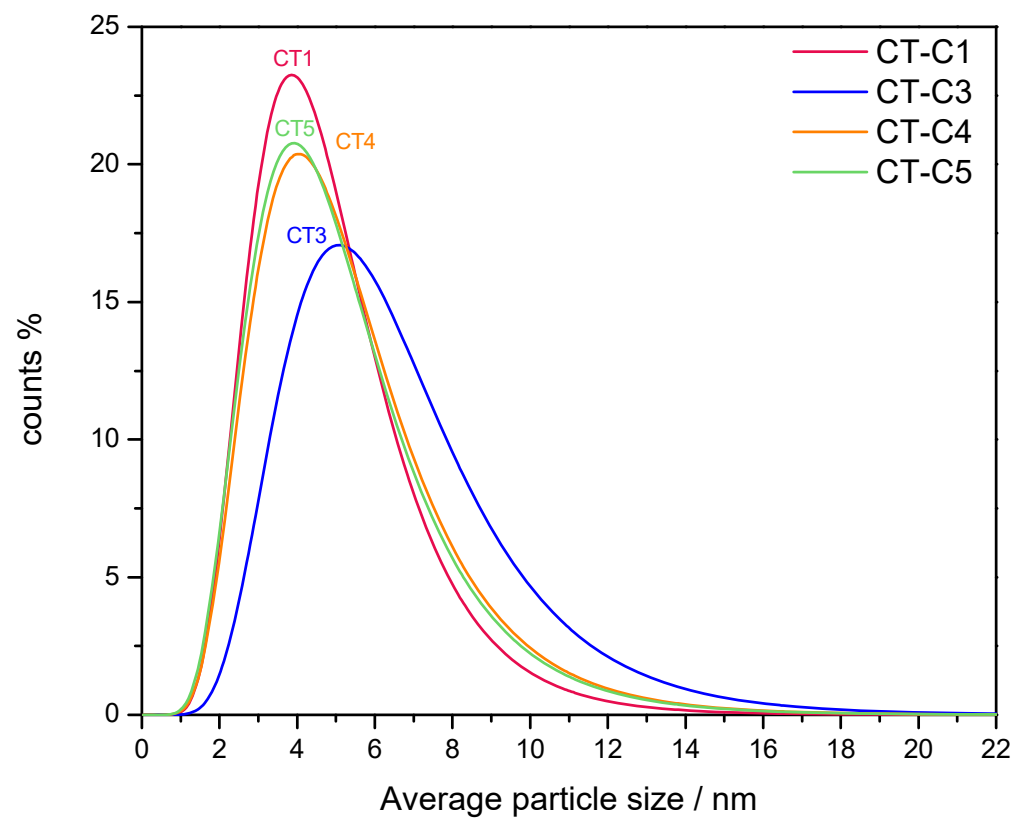


(c)

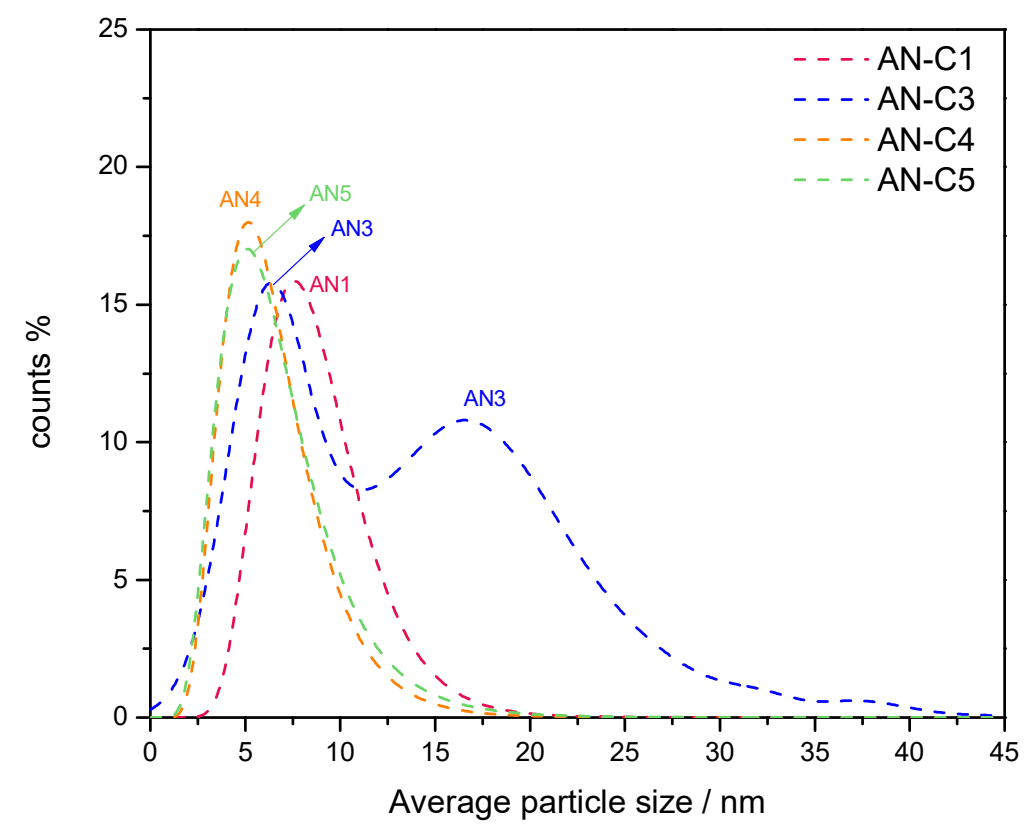

Figure 14. (a) Normal distribution obtained from the histograms for each catalyst anode and cathode. Detail on the normal distribution for (b) the cathode (CT) and (c) the anode (AN) of the different MEAs.

\section{7.- Analysis of the water produced inside the stack}

In order to know the effects of the tests on the degradation of the MEAs, the concentration of phosphorus and platinum in water samples collected from both the anode and the cathode sides was determined by atomic emission spectrometry coupled with inductive plasma (ICPAES). A first result to be highlighted is that the physical appearance of the condensed water of both electrodes was different. In particular, the water collected from the cathode sides was transparent, while that of the anode ones was cloudy. Two different samples were analyzed. Number 1 corresponds to the water collected just before the starvation tests, and number 2 to the water collected at the end of the starvation tests. The results are summarized in Table 2. An interesting result to be pointed out is that no presence of platinum was measured over the detection limit of the applied technique (50 ppb).

Table 2. Analysis by ICP-AES of the two samples of water collected from anodes and cathodes

\begin{tabular}{ccccc}
\hline \multirow{2}{*}{ Samples } & \multicolumn{2}{c}{ Anode sides } & \multicolumn{2}{c}{ Cathode sides } \\
\cline { 2 - 5 } & $\mathbf{P}\left(\mathrm{mg} \mathrm{l}^{-1}\right)$ & $\mathbf{p H}$ & $\mathbf{P}\left(\mathrm{mg} \mathrm{l}^{-1}\right)$ & $\boldsymbol{p H}$ \\
\hline $\mathbf{1}$ & 0.16 & 6.2 & 0.23 & 4.2 \\
\hline $\mathbf{2}$ & 2.1 & 6.1 & 0.47 & 4.1 \\
\hline
\end{tabular}


The average phosphorus content in the cathode samples doubled (from 0.23 to $0.47 \mathrm{mg} \mathrm{l}^{-1}$ ) after the starvation tests. However, a drastic increase (about 13 times) was observed for the phosphorus concentration in the samples collected from the anode sides. These results indicate that the loss of the free phosphoric acid of the membrane is intensified by the starvation of reactant gases. The difference between the acidity values of the water collected from both anode and cathode sides could be explained by the different evaporation or diffusion rates at the working temperature [22]. In addition, when the stack was opened, the residues adhered to the plate at the anode side of the cell 3 were washed with distilled water and the effluent was collected and analyzed. The phosphorus concentration obtained reached $330 \mathrm{mg} \mathrm{l}^{-1}$, which indicates that the physicochemical degradation of the membrane caused by the induced starvation tests increases the loss of phosphoric acid from the polymer. These results confirm that the severe starvation of reactant gases is very aggressive for the MEAs, and eventually causes their total degradation.

\section{4.- Conclusions}

With the detailed study performed with a 5-cell stack specifically designed to allow the variation of the individual gas supply to any given cell, the effect of the starvation of reactant gases on the performance and degradation of the affected cell and its neighbors was analyzed. To this end, two different tests were performed at the central cell denoted as moderate and severe starvation, depending on the intensity of the limitation imposed to the gases flowrate. Some relevant and novel results were obtained. It has been verified that the effects caused by a moderate starvation of the reactant gases in a cell are reversible. On the contrary, the damages caused by an aggressive gas starvation, maintained for a given time (30 min.), are irreversible. It has also been confirmed that the behavior of the rest of the cells was not affected during the two tests. While the voltage produced by the central cell decreased due to the gas starvation, the voltage generated by the rest of cells slightly improved. This unexpected performance is explained because the current produced by the stack is notably reduced when the potential of the affected cell is inverted. Consequently, the voltage of the unaffected cells increases to match the one corresponding to the actual current yielded.

Visual inspection of the MEA corresponding to the starved cell has shown obvious damage after the starvation tests. It has been verified that on the gas diffusion layer (GDL) of the anode 
side there were some scorched zones, indicative of a significant increase in local temperature. This hypothesis was also confirmed by the post-mortem analysis performed by SEM-EDX. It was detected that the different layers were clearly separated. The thickness of the catalyst layer of the anode side had decreased significantly, and the polymeric membrane was calcined, appearing crystallized.

XRD and TEM analyses showed that in general, anodes suffered more degradation than cathodes, in particular, in the starved cell, which presented both a degraded carbon support and a great agglomeration of Pt particles. It was verified that the Pt crystallite size for both anodes and cathodes almost doubled after the stack operation, being more evident in the case of the anode sides. The size of the Pt crystallite at the anode from the starved cell increased 4,6 times with respect to the original size, whereas the cathode, kept the same trend as the other cells. These results confirm that the starvation of hydrogen causes an aggressive degradation for the catalyst, due to the water electrolysis and carbon corrosion suffered when the potential in the anode rises.

Finally, the amount of phosphorus increased about 13 times for the water sample collected from the anode sides after the tests. The phosphorus concentration obtained from the residues adhered to the plate at the anode side of cell 3 indicates that the physicochemical degradation of the membrane caused for the induced starvation tests increases the loss of phosphoric acid from the polymer.

These results indicate that a severe starvation acts very aggressively on the MEA, and eventually causes its total and irreversible degradation. Nevertheless, the consequences of working with one cell affected with gas starvation do not propagate to the neighboring ones. So, the stack can still work but with a decreased power due to the decrease in the yielded current. This result throws some light to the critical durability challenges faced by hightemperature PEMFCs stacks.

\section{Acknowledgments}

Authors acknowledge the financial support of the Secretariat of State for Research of the Spanish Ministry of Economy and Competitiveness under project DPI2015-69286-C3-1-R, and the Spanish Ministry of Science, Innovation and Universities under the project RTI2018096001-B-C31. Support of the Regional Government of Aragon to the Fluid Mechanics for a Clean Energy Research Group (T01_17R) of the LIFTEC is also acknowledged. C. Alegre 
acknowledges the support of MINECO for her Juan de la Cierva contract and L. Álvarez-Manuel acknowledges the funding provided by the European Social Fund and CSIC under the Youth Employment Initiative. Authors also acknowledge Dr. M.J. Lázaro from the Instituto de Carboquímica for performing the physical-chemical characterization.

\section{References}

[1] (eds.) RKP and LAM. IPCC, 2014: Climate Change 2014: Synthesis Report. Contribution of Working Groups I, II and III to the Fifth Assessment Report of the Intergovernmental Panel on Climate Change. n.d.

[2] International Energy Agency I. TRANSPORT, ENERGY AND CO2 Moving Toward Sustainability. n.d.

[3] International Energy Agency I. CO2 Emissions from Fuel Combustion 2017 - Highlights. n.d.

[4] Niakolas DK, Daletou M, Neophytides SG, Vayenas CG. Fuel cells are a commercially viable alternative for the production of clean energy. Ambio 2016;45:32-7. doi:10.1007/s13280-015-0731-z.

[5] Wang Y, Chen KS, Mishler J, Cho SC, Adroher XC. A review of polymer electrolyte membrane fuel cells: Technology, applications, and needs on fundamental research. Appl Energy 2011;88:981-1007. doi:10.1016/J.APENERGY.2010.09.030.

[6] Sebastián D, Baglio V, Sebastián D, Baglio V. Advanced Materials in Polymer Electrolyte Fuel Cells. Materials (Basel) 2017;10:1163. doi:10.3390/ma10101163.

[7] Barreras F, Maza M, Lozano A, Báscones S, Roda V, Barranco JE, et al. Design and development of a multipurpose utility AWD electric vehicle with a hybrid powertrain based on PEM fuel cells and batteries. Int J Hydrogen Energy 2012;37:15367-79. doi:10.1016/j.ijhydene.2012.06.091.

[8] Kojima K, Fukazawa K. Current Status and Future Outlook of Fuel Cell Vehicle Development in Toyota. ECS Trans 2015;69:213-9. doi:10.1149/06917.0213ecst.

[9] Roda V, Carroquino J, Valiño L, Lozano A, Barreras F. Remodeling of a commercial plug-in battery electric vehicle to a hybrid configuration with a PEM fuel cell. Int J Hydrogen Energy 2018;43:16959-70. doi:10.1016/j.ijhydene.2017.12.171.

[10] Barreras F, Lozano A, Roda V, Barroso J, Martín J. Optimal design and operational tests of a high-temperature PEM fuel cell for a combined heat and power unit. Int. J. 
Hydrogen Energy, vol. 39, Pergamon; 2014, p. 5388-98.

doi:10.1016/j.ijhydene.2013.11.070.

[11] Santangelo PE, Tartarini P. Fuel cell systems and traditional technologies. Part I: Experimental CHP approach. Appl Therm Eng 2007;27:1278-84. doi:10.1016/J.APPLTHERMALENG.2006.11.002.

[12] Milcarek RJ, Ahn J, Zhang J. Review and analysis of fuel cell-based, micro-cogeneration for residential applications: Current state and future opportunities. Sci Technol Built Environ 2017;23:1224-43. doi:10.1080/23744731.2017.1296301.

[13] Zhang L, Chae S-R, Hendren Z, Park J-S, Wiesner MR. Recent advances in proton exchange membranes for fuel cell applications. Chem Eng J 2012;204-206:87-97. doi:10.1016/J.CEJ.2012.07.103.

[14] Araya SS, Zhou F, Liso V, Sahlin SL, Vang JR, Thomas S, et al. A comprehensive review of PBI-based high temperature PEM fuel cells. vol. 41. Pergamon; 2016. doi:10.1016/j.ijhydene.2016.09.024.

[15] Zhang J, Tang Y, Song C, Zhang J, Wang H. PEM fuel cell open circuit voltage (OCV) in the temperature range of $23^{\circ} \mathrm{C}$ to $120^{\circ} \mathrm{C}$. J Power Sources 2006;163:532-7. doi:10.1016/j.jpowsour.2006.09.026.

[16] Chandan A, Hattenberger M, El-kharouf A, Du S, Dhir A, Self V, et al. High temperature (HT) polymer electrolyte membrane fuel cells (PEMFC) - A review. J Power Sources 2013;231:264-78. doi:10.1016/J.JPOWSOUR.2012.11.126.

[17] Rosli RE, Sulong AB, Daud WRW, Zulkifley MA, Husaini T, Rosli MI, et al. A review of hightemperature proton exchange membrane fuel cell (HT-PEMFC) system. Int J Hydrogen Energy 2017;42:9293-314. doi:10.1016/J.IJHYDENE.2016.06.211.

[18] Aricò AS, Baglio V, Antonucci V. Composite Membranes for High Temperature Direct Methanol Fuel Cells. Membr. Energy Convers., Weinheim, Germany: Wiley-VCH Verlag GmbH \& Co. KGaA; 2008, p. 123-67. doi:10.1002/9783527622146.ch5.

[19] Park J, Oh H, Ha T, Lee Y II, Min K. A review of the gas diffusion layer in proton exchange membrane fuel cells: Durability and degradation. Appl Energy 2015;155:866-80. doi:10.1016/J.APENERGY.2015.06.068.

[20] Wang J. System integration, durability and reliability of fuel cells: Challenges and solutions. Appl Energy 2017;189:460-79. doi:10.1016/J.APENERGY.2016.12.083.

[21] Stassi A, Gatto I, Saccà A, Baglio V, Aricò A, Stassi A, et al. Enhancement of Oxygen 
Reduction and Mitigation of lonomer Dry-Out Using Insoluble Heteropoly Acids in Intermediate Temperature Polymer-Electrolyte Membrane Fuel Cells. Energies 2015;8:7805-17. doi:10.3390/en8087805.

[22] Yu S, Xiao L, Benicewicz BC. Durability studies of PBI-based high temperature PEMFCs. Fuel Cells, vol. 8, WILEY-VCH Verlag; 2008, p. 165-74. doi:10.1002/fuce.200800024.

[23] Lufrano F, Gatto I, Staiti P, Antonucci V, Passalacqua E. Sulfonated polysulfone ionomer membranes for fuel cells. Solid State Ionics, vol. 145, Elsevier; 2001, p. 47-51. doi:10.1016/S0167-2738(01)00912-2.

[24] Wu J, Yuan XZ, Martin JJ, Wang H, Zhang J, Shen J, et al. A review of PEM fuel cell durability: Degradation mechanisms and mitigation strategies. J Power Sources 2008;184:104-19. doi:10.1016/J.JPOWSOUR.2008.06.006.

[25] Schmittinger W, Vahidi A. A review of the main parameters influencing long-term performance and durability of PEM fuel cells. J Power Sources 2008;180:1-14. doi:10.1016/J.JPOWSOUR.2008.01.070.

[26] Galbiati S, Baricci A, Casalegno A, Marchesi R. Degradation in phosphoric acid doped polymer fuel cells: A $6000 \mathrm{~h}$ parametric investigation. Int J Hydrogen Energy 2013;38:6469-80. doi:10.1016/J.IJHYDENE.2013.03.012.

[27] Kerr R, García HR, Rastedt M, Wagner P, Alfaro SM, Romero MT, et al. Lifetime and degradation of high temperature PEM membrane electrode assemblies. Int J Hydrogen Energy 2015;40:16860-6. doi:10.1016/J.IJHYDENE.2015.07.152.

[28] Kim J-R, Yi JS, Song T-W. Investigation of degradation mechanisms of a high-temperature polymer-electrolyte-membrane fuel cell stack by electrochemical impedance spectroscopy. J Power Sources 2012;220:54-64. doi:10.1016/j.jpowsour.2012.07.129.

[29] Cleemann LN, Buazar F, Li Q, Jensen JO, Pan C, Steenberg T, et al. Catalyst degradation in high temperature proton exchange membrane fuel cells based on acid doped polybenzimidazole membranes. Fuel Cells 2013;13:822-31. doi:10.1002/fuce.201200186.

[30] Oh H-S, Lee J-H, Kim H. Electrochemical carbon corrosion in high temperature proton exchange membrane fuel cells. Int J Hydrogen Energy 2012;37:10844-9. doi:10.1016/j.ijhydene.2012.04.095.

[31] Bevilacqua N, George MG, Galbiati S, Bazylak A, Zeis R. Phosphoric Acid Invasion in High Temperature PEM Fuel Cell Gas Diffusion Layers. Electrochim Acta 2017;257:89-98. 
doi:10.1016/J.ELECTACTA.2017.10.054.

[32] Pinar FJ, Cañizares P, Rodrigo MA, Úbeda D, Lobato J. Long-term testing of a hightemperature proton exchange membrane fuel cell short stack operated with improved polybenzimidazole-based composite membranes. J Power Sources 2015;274:177-85. doi:10.1016/J.JPOWSOUR.2014.08.136.

[33] Bae SJ, Kim S-J, Lee J-H, Song I, Kim N-I, Seo Y, et al. Degradation pattern prediction of a polymer electrolyte membrane fuel cell stack with series reliability structure via durability data of single cells. Appl Energy 2014;131:48-55. doi:10.1016/J.APENERGY.2014.05.064.

[34] De las Heras A, Vivas FJ, Segura F, Redondo MJ, Andújar JM. Air-cooled fuel cells: Keys to design and build the oxidant/cooling system. Renew Energy 2018;125:1-20. doi:10.1016/J.RENENE.2018.02.077.

[35] Chen Y-S, Yang C-W, Lee J-Y. Implementation and evaluation for anode purging of a fuel cell based on nitrogen concentration. Appl Energy 2014;113:1519-24. doi:10.1016/J.APENERGY.2013.09.028.

[36] Alegre C, Álvarez-Manuel L, Mustata R, Valiño L, Lozano A, Barreras F. Assessment of the durability of low-cost Al bipolar plates for High Temperature PEM fuel cells. Int J Hydrogen Energy 2018. doi:10.1016/J.IJHYDENE.2018.07.070.

[37] Taniguchi A, Akita T, Yasuda K, Miyazaki Y. Analysis of electrocatalyst degradation in PEMFC caused by cell reversal during fuel starvation. J Power Sources 2004;130:42-9.

[38] Natarajan D, Van Nguyen T. Current distribution in PEM fuel cells. Part 1: Oxygen and fuel flow rate effects. AIChE J 2005;51:2587-98. doi:10.1002/aic.10545.

[39] Yousfi-Steiner N, Moçotéguy P, Candusso D, Hissel D. A review on polymer electrolyte membrane fuel cell catalyst degradation and starvation issues: Causes, consequences and diagnostic for mitigation. J Power Sources 2009;194:130-45. doi:10.1016/J.JPOWSOUR.2009.03.060.

[40] Hu Z, Xu L, Li J, Hu J, Xu X, Du X, et al. A cell interaction phenomenon in a multi-cell stack under one cell suffering fuel starvation. Energy Convers Manag 2018;174:465-74. doi:10.1016/J.ENCONMAN.2018.08.062.

[41] Jeppesen C, Araya SS, Sahlin SL, Thomas S, Andreasen SJ, Kær SK. Fault detection and isolation of high temperature proton exchange membrane fuel cell stack under the influence of degradation. J Power Sources 2017;359:37-47. 
doi:10.1016/J.JPOWSOUR.2017.05.021.

[42] Rezaei Niya SM, Phillips RK, Hoorfar M. Study of anode and cathode starvation effects on the impedance characteristics of proton exchange membrane fuel cells. J Electroanal Chem 2016;775:273-9. doi:10.1016/J.JELECHEM.2016.06.013.

[43] Zhang G, Shen S, Guo L, Liu H. Dynamic characteristics of local current densities and temperatures in proton exchange membrane fuel cells during reactant starvations. Int J Hydrogen Energy 2012;37:1884-92. doi:10.1016/J.IJHYDENE.2011.04.120.

[44] Liu Z, Yang L, Mao Z, Zhuge W, Zhang Y, Wang L. Behavior of PEMFC in starvation. J Power Sources 2006;157:166-76. doi:10.1016/J.JPOWSOUR.2005.08.006.

[45] Wei ZD, Ji MB, Hong Y, Sun CX, Chan SH, Shen PK. MnO2-Pt/C composite electrodes for preventing voltage reversal effects with polymer electrolyte membrane fuel cells. J Power Sources 2006;160:246-51. doi:10.1016/J.JPOWSOUR.2006.01.028.

[46] Lee C-Y, Chiang Y-C, Weng F-B, Li S-C, Wu P-H, Yueh H-I. Flexible micro temperature, voltage and current sensors for local real-time microscopic diagnosis inside high temperature proton exchange membrane fuel cell stack. Renew Energy 2017;108:12631. doi:10.1016/J.RENENE.2017.02.015.

[47] Mitsuda K, Murahashi T. Air and fuel starvation of phosphoric acid fuel cells: A study using a single cell with multi-reference electrodes. J Appl Electrochem 1991;21:524-30. doi:10.1007/BF01018605.

[48] Song R-H, Kim C-S, Shin DR. Effects of flow rate and starvation of reactant gases on the performance of phosphoric acid fuel cells. J Power Sources 2000;86:289-93. doi:10.1016/S0378-7753(99)00450-4.

[49] Zhou F, Andreasen SJ, Kær SK. Experimental study of cell reversal of a high temperature polymer electrolyte membrane fuel cell caused by H2 starvation. Int J Hydrogen Energy 2015;40:6672-80.

[50] Zhou F, Andreasen SJ, Kær SK, Yu D. Analysis of accelerated degradation of a HT-PEM fuel cell caused by cell reversal in fuel starvation condition. Int J Hydrogen Energy 2015;40:2833-9. doi:10.1016/J.IJHYDENE.2014.12.082.

[51] Lozano A, Barreras F, Valiño L, Marín C. Imaging of gas flow through a porous medium from a fuel cell bipolar plate by laser-induced fluorescence. Exp Fluids 2007;42:301-10. doi:10.1007/s00348-006-0241-7.

[52] Barreras F, López AM, Lozano A, Barranco JE. Experimental study of the pressure drop in 
the cathode side of air-forced Open-cathode proton exchange membrane fuel cells. Int J Hydrogen Energy 2011;36:7612-20. doi:10.1016/J.IJHYDENE.2011.03.149.

[53] López AM, Barreras F, Lozano A, García JA, Valiño L, Mustata R. Comparison of water management between two bipolar plate flow-field geometries in proton exchange membrane fuel cells at low-density current range. J Power Sources 2009;192:94-9. doi:10.1016/J.JPOWSOUR.2008.12.082.

[54] Dapozol (R)-100 MEA Manual, Technical documentation provided by Danish Power Systems (2017) 2017.

[55] Hargreaves JSJ. Some considerations related to the use of the Scherrer equation in powder X-ray diffraction as applied to heterogeneous catalysts. Catal Struct React 2016;2:33-7. doi:10.1080/2055074X.2016.1252548.

[56] Ralph TR, Hogarth MP. Catalysis for Low Temperature Fuel Cells | PART II: The Anode Challenges. Platin Met Rev 2002;46:117.

[57] Daletou MK, Kallitsis JK, Voyiatzis G, Neophytides SG. The interaction of water vapors with $\mathrm{H} 3 \mathrm{PO} 4$ imbibed electrolyte based on PBI/polysulfone copolymer blends. J Memb Sci 2009;326:76-83.

[58] Mandal P, Hong BK, Oh J-G, Litster S. Understanding the voltage reversal behavior of automotive fuel cells. J Power Sources 2018;397:397-404. doi:10.1016/J.JPOWSOUR.2018.06.083.

[59] Wen C-Y, Lin Y-S, Lu C-H. Performance of a proton exchange membrane fuel cell stack with thermally conductive pyrolytic graphite sheets for thermal management. J Power Sources 2009;189:1100-5. doi:10.1016/j.jpowsour.2008.12.103.

[60] Gu T, Shimpalee S, Van Zee JW, Chen C-Y, Lin C-W. A study of water adsorption and desorption by a PBI-H3PO4 membrane electrode assembly. J Power Sources 2010;195:8194-7. doi:10.1016/J.JPOWSOUR.2010.06.063.

[61] Guo H, Wang MH, Ye F, Ma CF. Experimental study of temperature distribution on anodic surface of MEA inside a PEMFC with parallel channels flow bed. Int J Hydrogen Energy 2012;37:13155-60. doi:10.1016/j.ijhydene.2012.03.138.

[62] Noorkami M, Robinson JB, Meyer Q, Obeisun OA, Fraga ES, Reisch T, et al. Effect of temperature uncertainty on polymer electrolyte fuel cell performance. Int J Hydrogen Energy 2014;39:1439-48. doi:10.1016/j.ijhydene.2013.10.156.

[63] Salva JA, Iranzo A, Rosa F, Tapia E. Experimental validation of the polarization curve and 
the temperature distribution in a PEMFC stack using a one dimensional analytical model. Int J Hydrogen Energy 2016;41:20615-32. doi:10.1016/j.ijhydene.2016.09.152.

[64] Guo H, Wang MH, Liu JX, Nie ZH, Ye F, Ma CF. Temperature distribution on anodic surface of membrane electrode assembly in proton exchange membrane fuel cell with interdigitated flow bed. J Power Sources 2015;273:775-83. doi:10.1016/j.jpowsour.2014.09.159.

[65] Lin HL, Hsieh YS, Chiu CW, Yu TL, Chen LC. Durability and stability test of proton exchange membrane fuel cells prepared from polybenzimidazole/poly(tetrafluoro ethylene) composite membrane. J Power Sources 2009;193:170-4. doi:10.1016/j.jpowsour.2009.01.062. 